\title{
Should the Ranch Go Free Because the Constable Blundered? Gaining Coinpliance with Search and Seizure Standards in the Age of Asset Forfeiture
}

\author{
William Patrick Nelson $\dagger$
}

Asset forfeiture has become an increasingly popular tool for law enforcement agencies combatting traffickers in illegal narcotics. The technique not only deprives perpetrators of valuable property, but also subsidizes governmental organizations in their efforts to pursue criminals. Asset forfeiture thus provides an unusually significant incentive to law enforcement to violate Fourth Amendment standards in pursuit of property which might augment agency resources. This Comment documents the growth of asset forfeiture statutes and the enthusiasm of law enforcement officials toward forfeiture. The Comment describes the inadequacy of the traditional judicial mechanism, the exclusionary rule, to deter violations of the Fourth Amendment in the context of asset forfeiture. As it is currently applied, the exclusionary rule effectively permits governmental agencies to retain the benefits of unlawful seizures. As an alternative, the Comment suggests a rule that would prohibit the forfeiture of assets taken in violation of the Fourth Amendment, thereby creating a greater incentive for police compliance with search and seizure rules.

Once a disfavored backwater of American criminal law, asset forfeiture laws-which empower the government to strip offenders of their personal property, cash, and real estate-have been recommissioned and retooled as a major weapon in the war on drugs. Broad seizure authority, burden shifting provisions, and expedited procedures make asset forfeitures an effective tool for law enforcement agencies pursuing drug criminals. While forfeitures have dramatically increased in the last seven years-growing by more than $2000 \%$-drug traffickers have not been the only group affected. The lure of asset forfeitures has also led federal,

$\dagger$ Young Scholar, Earl Warren Legal Institute. B.A. 1982, University of California, Riverside; J.D. 1992, Boalt Hall School of Law, University of California, Berkeley. I wish to thank Professor Franklin Zimring for his advice, cajolery, and support, without which this Comment would have remained unwritten. 
state, and local law enforcement agencies to alter significantly the strategies with which they conduct the drug war.

The statutory forfeiture scheme entitles participating law enforcement agencies to collect a share of the proceeds from a successful asset forfeiture. ${ }^{1}$ Law enforcement thus has a power umique among government agencies: direct augmentation of the agency's budget through the performance of its designated function. Forfeiture money buys manpower and sophisticated equipment, and forfeited property such as cars, planes, and boats is pressed into law enforcement service, bypassing the normal budgetary process through which such benefits must normally be accrued. It is not difficult to see how this prospect serves as an incentive for law enforcement agencies to pursue forfeitures aggressively. The traditional law enforcement approaches to drug crime, interdicting drugs and apprehending offenders, must seem lackluster compared to the allure of forfeiture. Beeause of its powerful attraction, asset forfeiture has emerged as a popular alternative to criminal prosecution for law enforcement.

Law enforceinent agencies are not the only champions of asset forfeitures. Congress is understandably excited about the prospect of sharing some of the estimated $\$ 100$ billion in annual drug trade profits. ${ }^{2}$ The Department of Justice Asset Forfeiture Fund was set up to finance federal prison construction, ${ }^{3}$ federal drug enforcennent task forces, ${ }^{4}$ and other such programs. The laws undoubtedly appeal to the public as well. Much has been made of the " "poetic justice" " " of forcing drug traffickers to fund the war against crime and drugs through forfeitures. 5

In this atınosphere, hittle attention has been paid to the influence of the forfeiture explosion on its primary beneficiaries, participating law

1. The statute provides that "[w]henever property is civilly ... forfeited under this subchapter the Attorney General may ... transfer the property to any Federal agency or to any State or local law enforcement agency which participated directly in the seizure or forfeiture of the property ...." 21 U.S.C. $\$ 881(\mathrm{e})(1)(\mathrm{A})(1988)$.

2. Federal Drug Forfeiture Activities: Hearing Before the Subcomm. on Crime of the House Comm. on the Judiciary, 101st Cong., 1st Sess. 119 (1989) [hereinafter Federal Drug Forfeiture Activities].

Congress has been eager to fortify and broaden the forfeiture statute. For example, in 1984 Congress enacted Pub. L. No. 98-473, $\S 306,98$ Stat. 1837, 2050, which added subsection (a)(7) to 21 U.S.C. $\S 881$. The new subsection provided for the forfeiture of land used or intended to bc used to facilitate a violation of the drug laws.

3. 28 U.S.C. $\$ 524(\mathrm{c})(1)(\mathrm{H})(1988)$.

4. The High Intensity Drug Trafficking Areas program, which focuses federal law enforcement efforts on drug trouble spots in the United States, is one recipient of forfeited funds. The program was created as part of the Anti-Drug Abuse Act of 1988, Pub. L. No. 100-690, $\S 1005$ (c), 102 Stat. 4181, 4186.

5. Oversight of "High Risk" Asset Forfeiture Programs at the Justice Department and the Customs Service: Hearing Before the Senate Comm. on Governmental Affairs, 101st Cong., 2d Sess. 115 (1990) [hereinafter Oversight] (quoting EXECUTIVE OFFICE FOR ASSET Forfeiture, U.S. Dep'T of Justice, Federal Forfeiture of the INSTRUMents and Proceeds of Crime: The Program in a Nutshell 1 (1990) (quoting Attorney General Richard Thornburgh)). 
enforcement agencies. Perhaps under the assumption that there is no essential difference between pohce pursuit of criminals and police pursuit of cash, basic policy questions about police practices remain unasked. This Comment looks into one such unasked question: does the shift in law enforcement goals brought about by forfeiture call for re-evaluation and reformation of the mechanisms designed to deter police violations of Fourth Amendment standards?

In traditional law enforcement activities, the primary method of encouraging coinphance with Fourth Amendment standards has been the exclusionary rule, a judicially imposed reinedy designed to deter law enforceinent misconduct by prohibiting the admission at trial of evidence seized in violation of the Fourth Amendinent. However, application of the exclusionary rule in the unique setting of the forfeiture proceeding, what this Comment calls the "parallel application" of this rule, produces rather haphazard results. This Comment argnes that its current application in fact achieves little or no deterrent effect. Since the uulawful seizure of property does not bar its forfeiture, and the possession of the res is a legitimate law enforcement goal, in most situations there is little reason for a law enforceinent agency to be concerned about Fourth Amendment standards. Rather, given the powerful incentives to pursue forfeiture, it may make instrumental sense under this system for a law enforcement agency to embark on a systematic policy of Fourth Amendment violations.

The need for some mechanism to deter illegal search and seizure in the age of asset forfeitures is substantial. Despite its civil designation, asset forfeiture is far from being a simple civil event in the eyes of its subject. A victim of an unlawful search and seizure resulting in civil forfeiture suffers the saine unpleasant governmental invasion as a victim who is subsequently prosecuted criminally.

As the dust settles from the war on drugs, it is time for a fresh look at the possibility of fashioning an external sanction to deter law enforcenient violation of the Fourth Amendment. To the extent forfeiture of drug-related property has become an important goal of law enforcement agencies, those agencies must be demed the material fruits of unlawful seizures. The emphasis of the current Suprenie Court on deterrence in framing the exclusionary rule, which has previously justified a narrowing of evidentiary exclusions in criminal trials, requires by its own logic a broadly frained rule that prohibits law enforcenient agency retention of unlawfully seized property.

This Comment proposes a rule that would bar the forfeiture of any asset seized in violation of the Fourth Amendment. Given the powerful incentives driving law enforcement pursuit of assets and the effect of those incentives on law enforcenient goals and practices, the proposed 
rule could be an effective tool for gaining comphance with Fourth Amendment standards.

Part I of this Comment briefly reviews the nature of asset forfeiture laws generally, and then focuses on the drug forfeiture statute, 21 U.S.C. $\S 881$, specifically. This Part traces the growth of the statute's coverage from its origin when it defined a limited band of property as forfeitable through its evolution to its present inclusion of essentially any form of drug-related property. This Part then describes the statute's operation, focusing on the special features, procedural and otherwise, that make forfeiture an attractive tool for law enforcement. This is followed by a summary description of the disposition of forfeited property.

Part II charts the explosive growth of forfeiture proceeds in the 1980s, and then confronts the policy implications of this growth, arguing that asset forfeiture has become an accepted policy goal for participating law enforcement agencies. Regardless of the arrest and conviction of the drug offender/property owner, asset forfeiture is a desirable end in itself for these agencies. Evidence of this policy effect can be found in both law enforceinent stateinents and actions regarding forfeiture.

Part III explores deterrence of law enforcement violations of Fourth Amendment standards committed in the pursuit of forfeitable assets. After a summary review of the logic of deterrence, this Part addresses the exclusionary rule, which is based on, and justified by, this logic. The Comment concludes that whatever the efficacy of the exclusionary rule in its normal sphere of application, it cannot have any appreciable effect when law enforcement agents engage in instrumental pursuit of forfeitable assets. This is the result of the formahistic application of the exclusionary rule in the forfeitures context, based on a structural rather than functional paradigm: what this Comment calls "parallel application doctrime." Since the operation of the exclusionary rule has little or no effect on the outcome of a forfeiture proceeding, and a successful forfeiture produces considerable benefits, this Part argues law enforcement agents may have incentives to disregard Fourth Amendment standards in their pursuit of forfeitable assets.

Finally, Part IV presents a proposal for reform, a "desigued disincentive" that would act as a functional rather than structural equivalent to the exclusionary rule. This Part then contrasts the potential deterrent effects of the proposed rule with those of the exclusionary rule, arguing that the forfeiture explosion created an environment within participating law enforceinent agencies that is responsive to the type of disincentive to cominit Fourth Amendment violations contained in the proposed rule. The Part concludes with a discussion of the likelihood of the rule being implemented, its expected benefits, and its social costs. 
I

\section{ASSET FORFEITURE}

\section{A. The Nature of Asset Forfeitures}

The concept of forfeiture has a long history in the law. ${ }^{6}$ Some historians trace the institution back to at least Biblical times, pointing to the laws of the Old Testament: "If an ox gore a man or woman, and they die, he shall be stoned: and his flesh shall not be eaten, but the owner of the ox shall be quit."7

Modern forfeiture statutes bear the unmistakable inarks of their ancestors. Foremost among these birthmarks is the notion of "guilty property" - that tlirough soine illicit use or activity, the instrument itself is tainted and subject to confiscation, apart from and regardless of the guilt of its owner. This characterization is obviously a legal fiction. In a society where jurisprudence is couched in terms of the duty of care, blame does not fall on the dog tliat bites or on the train that derails; ratlier, we look to see who has responsibility for controlling the liarmful instruinentality, and whether that responsibility has been breached. ${ }^{8}$

This fiction nevertheless persists in forfeiture law, perhaps because it is a useful fiction. Modern forfeiture statutes are characterized as civil in rem actions against property; ${ }^{9}$ the owner is not even a nominal party. ${ }^{10}$ As discussed in Section I.C, this procedural approach affords the government several advantages in its pursuit of the res, which make forfeiture a relatively simple matter.

Confiscation has traditionally played only a minor role in American criminal law enforcement. ${ }^{11}$ Now the forfeiture device lias been dusted

6. Space does not permit an extended discussion of the history of forfeiture laws. This Section is therefore limited to a review of the ancient basis of forfeitures laws, the remnants of which exist in today's laws. For a broader discussion of their pedigree, see generally Jacob J. Finkelstein, The Goring Ox: Some Historical Perspectives on Deodands, Forfeitures, Wrongful Death and the Western Notion of Sovereignty, 46 TEMP. L.Q. 169 (1973).

7. Exodus 21:28.

8. The term "contraband" helps illustrate how property itself can be secn as guilty. It is unlawful merely to possess certain items of property. For example, I may not own a howitzer, no matter what good use I might put it to $m$ the name of home security. In the same vein, ownership of an uncontrollable ox is forbidden, regardless of the ox's usefulness in plowing a field. However, it is difficult to imagine characterizing a house, cash, or a BMW as "uncontrollable" in this way without revealing the real "guilty" party: the property owner. The Supreme Court has described this type of forfeitable property as "derivative" contraband. See One 1958 Plymouth Sedan v. Pennsylvania, 380 U.S. 693, 699 (1965).

9. See, e.g., United States v. 303 W. 116th St., 901 F.2d 288, 290 (2d Cir. 1990) ("The government initiated this in rem civil action ....").

10. Since the forfeiture statute declares assets to be property of the government at the moment of the commission of the proscribed act, 21 U.S.C. $\$ 881(\mathrm{~h})$ (1988), the property owner is commonly identified in forfeiture cases as the "claimant"-that is, the claimant to the government's property. See, e.g., United States v. D.K.G. Appaloosas, Inc., 829 F.2d 532, 534 (5th Cir. 1987), cert. denied, 485 U.S. 976 (1988).

11. For example, the Act of July 17, 1862, ch. 195, 12 Stat. 589, allowed the seizure and confiscation of northern property owned by southern rebels. For a discussion of the Civil War 
off and outfitted for the modern age, with a new mission and new power: fighting crime, particularly drug crime. To understand the interaction between forfeiture, a doctrine that predates the Fourth Amendment, and the search and seizure rules generated by that constitutional requirement, a review of the modern forfeiture statute and its operation is necessary.

\section{B. Development of 21 U.S.C. $\& 881$-The "Modern" Forfeiture Statute}

Nearly every Congress has been called upon to "do something" about crime, but few Congresses responded more prohifically than the Ninety-First. That Congress passed the Organized Crime Control Act of 1970 (the original RICO statute), ${ }^{12}$ and the Comprehensive Drug Abuse and Control Act of $1970,{ }^{13}$ which mcluded the original version of the present drug forfeiture act.

It is fitting that Congress passed these two Acts together; they are fraternal twins in their approach to combatting organized networks of crime. ${ }^{14}$ Both depart from the traditional criminal justice model, which focuses on prosecuting offenders. Instead, the new statutes proceed from the recoginition that drug-related and other organized crimes have an economic basis. Selective proseeution of offenders cannot have a lasting impact, because "as long as the flow of money continues, such prosecutions will only result in a compulsory retirement and promotion system as new people step forward to take the place of those convicted."15 The two Acts set up statutory schemes to attack the economic basis of group crime by depriving offenders of the fruits of their illegal activities. ${ }^{16}$

Confiscation Acts, see James G. Randall, Constitutional Problems Under Lincoln 275. 341 (1913).

12. Pub. L. No. $91-452, \S 901,84$ Stat. $922,941-47$ (codified as amended at 18 U.S.C. $\S \S 1961$ 1968 (1988 \& Supp. II 1990)). The RICO (Racketeer Influenced and Corrupt Organizations) statute contains both civil and criminal forfeiture provisions. 18 U.S.C. $\$ \S 1963-1964$ (1988 \& Supp. II 1990). The analysis in this Comment is applicable to the RICO statute to the extent that its civil provisions are similar to those embodied in the drug forfeiture statute.

13. Pub. L. No. $91-513, \S 511,84$ Stat. 1236, 1276 (codified as amended at 21 U.S.C. $\S 881$ (1988 \& Supp. II 1990)).

14. From today's perspective, the 91 st Congress seems prophetic. Although both the RICO and asset forfeiture statutes are now indispensable parts of the law enforcement scheme, neither received much attention in their early years. The RICO statute did not become a powerful law enforcement tool and the subject of considerable legal debate until a number of years after its passage. The statute then proved to be so effective and so popular with law enforcement that it spawned a frenzy among the states to produce their own "baby" RICO statutes-state versions of the federal original. See Gerard E. Lynch, RICO: The Crime of Being a Criminal, 87 Colum. L. REV. 661, 715 n.236 (1987). Although the drug forfeiture statute has received soinewhat less attention than its sibling, its growth has followed a parallel course in the late 1980 s, inspiring a spate of state laws aimed at the same res. See MODEL Forfeiture of DrUg Profits ACT, reprinted in U.S. DEP'T OF JUSTICE, DRUG AGENTS' GUIDE TO ForfeITURE of ASSETS at A2-A8 (1987 Revision) (to amend the Uniform Controlled Substances Act) [hereinafter DRUG AGENTS' GU1DE].

15. S. ReP. No. 617, 91st Cong., 1st Sess. $78-79$ (1969) (discussing RICO forfeiture provisions).

16. The report accompanying the 1970 statute reads:

What is needed here ... are new approaches that will deal not only with individuals, but 
Removing the proceeds of crime, according to the logic of the Acts, would remove the incentive to commit crime.

As enacted in 1970, the drug forfeiture statute, 21 U.S.C. $\$ 881$, had a himited apphication. Only certain items were forfeitable: equipment, apparatus, and containers used in the production or storage of drugs. ${ }^{17}$ The exception was section (a)(4), authorizing the forfeiture of conveyances used or intended for use in facilitating drug crime-boats, planes, and cars. ${ }^{18}$ The statute did not see widespread application $\mathrm{m}$ its first ten years, due im part to its limited coverage. ${ }^{19}$

In 1978, however, Congress brought 21 U.S.C. $\S 881$ firmly into the modern era with the addition of subsection (a)(6), providing for the forfeiture of

[a]11 moneys, negotiable instruments, securities, or other things of value furnished or intended to be furnished by any person in exchange for a controlled substance in violation of this [subchapter], all proceeds traceable to such an exchange, and all moneys, negotiable instruments, and securities used or intended to be used to facilitate any violation of this subchapter. ${ }^{20}$

The sweep of this amendinent is considerable. Anything of value used to procure a controlled substance is now forfeitable. Any proceeds traceable to such a transaction are forfeitable. Furthermore, any money or negotiable imstrument intended to be used to facilitate any felony violation of the federal drug laws is forfeitable. Durmg the amendment's

also with the economic base through which those individuals constitute such a serious threat to the economic well-being of the Nation. In short, an attack must be made on their source of economic power itself, and the attack must take place on all available fronts.

Id. at 79 .

17. The following shall be subject to forfeiture to the United States and no property right shall exist in them:

(1) All controlled substances which have been manufactured, distributed, dispensed, or acquired in violation of this title.

(2) All raw materials, products, and equipment . . . which are used, or intended for use, in manufacturing, coinpounding, processing, delivering, importing, or exporting any controlled substance $\mathrm{m}$ violation of this title.

(3) All property which is used, or intended for use, as a container for property described in paragraph (1) or (2).

(4) All conveyances, mcluding aircraft, vehicles, or vessels, which are used, or are intended for use, to transport, or im any manner to facilitate the transportation, sale, receipt, possession, or concealment of property described in paragraph (1) or (2) . . .

(5) All books, records, and research ... which are used, or intended for use, in violation of this title.

Comprehensive Drug Abuse Prevention and Control Act of 1970, Pub. L. No. 91-513, §511, 84 Stat. 1236, 1276 (codified as amended at 21 U.S.C. $\$ 881$ (a) (1988 \& Supp. II 1990)).

18. Id.

19. By 1979 , less than $\$ 30,000,000$ had been forfeited under all forfeiture statutes. GENERAL Accounting OfFice, Asset Forfeiture-A Seldom Used Tool in Combatting Drug TRAFFICKING 13 (1981).

20. Psychotropic Substances Act of 1978, Pub. L. No. 95-633, § 301(a), 92 Stat. 3768, 3777 (codified at 21 U.S.C. $\$ 881$ (a)(6) (1988)). The amendment to $\S 881$ is appended to the Act, alınost as an afterthought. As a result, there is scant legislative history for subsection (a)(6), which is the keystone of the drug forfeiture law. 
first year, the quantity of DEA forfeitures increased twenty times over the previous year. ${ }^{21}$

Congress added the last major piece of the drug forfeiture statute in 1984. Reaffirming their commitment to deter drug trafficking by stripping drug traffickers of their economic power, ${ }^{22}$ congressional supporters of forfeiture noted that although drug trade profits were estimated to be in the billions of dollars, seized assets reached only into the millions. They placed partial blame on the "limitations and ambiguities" of current forfeiture laws for law enforcement's failure to reach its full potential. $^{23}$

In an attempt to remedy this perceived limitation, Congress added subsection (a)(7) to $\S 881$. The hist of assets subject to forfeiture now includes

[a]11 real property, including any right, title, and interest [including any leasehold interest] in the whole of any lot or tract of land and any ... improvennents, which is used, or intended to be used, in any inanner or part, to commit, or to facilitate the coinunission of, a violation of this title punishable by inore than one year's inprisoninent. ${ }^{24}$

There is legislative history suggesting Congress imtended this section to authorize forfeiture of drug storage or manufacturing facilities only. ${ }^{25}$ However, the statute is much broader on its face, and courts and prosecutors have been disinclined to imterpret the statute so narrowly. ${ }^{26}$ As a

21. See General Accounting OFfice, supra note 19, at 59.

22. Today, few in the Congress or the law enforcement community fail to recognize that the traditional criminal sanctions of fine and inprisonment are inadequate to deter or punish the enormously profitable trade in dangerous drugs which, with its inevitablc attendant violence, is plaguing the country. Clearly, if law enforcenient efforts to combat ... drug trafficking are to be successful, they must include an attack on the economic aspects of these crimes. Forfeiture is the mechanisn through which such an attack may be made.

S. REP. No. 225, 98th Cong., 1st Sess. 191 (1983), reprinted in 1984 U.S.C.C.A.N. 3182, 3374.

23. Id. at 194, reprinted in 1984 U.S.C.C.A.N. at 3377 (footnote onitted).

24. Conuprehensive Crime Control Act of 1984, Pub. L. No. 98-473, § 306, 98 Stat. 1837, 2050.

25. Under current law, if a person uses a boat or ear to transport narcotics or uses equipnient to nuanufacture dangerous drugs, his use of the property renders it subject to civil forfeiture. But if he uses a secluded barn to store tons of marihuana or uses his house as a nianufacturing laboratory ... there is no provision to subject his real property to civil forfeiture, even though its use was indispensable to the conınission of a major drug offense and the prospect of the forfeiture of the property would have been a powerful deterrent.

S. REP. No. 225, supra note 22, at 195 (footnote omitted); see also H.R. REP. No. 845, 98th Cong., 2d Sess., pt. 2, at 7 (1984) (amendment would "permit the civil forfeiture of land and buildings used, or intended to be used, for holding, storage or cultivation of controlled substances . . . . Current law is unclear as to whether warehouses or other buildings can be forfeited and land cannot be forfeited at the present time.").

26. See United States v. 916 Douglas Ave., 903 F.2d 490, $492-93$ (7th Cir. 1990) (rejecting "substantial connection" test based on legislative history argunient, while upholding forfeiture of a house whose telephone was used to facilitate the sale of two ounces of cocaine because the house was used "in any manner or part"), cert. denied, 111 S. Ct. 1090 (1991). 
result, private residences, ${ }^{27}$ hotels, ${ }^{28}$ ranches, ${ }^{29}$ and fraternity houses ${ }^{30}$ in short, any real property whether or not used to manufacture or store drugs-are subject to forfeiture if used or intended to be used to commit a felony drug offense. Not surprisingly, some of the most striking forfeitures cases are prosecuted under this section.

\section{Practice Under 21 U.S.C. $\$ 881$}

The practical operation of the drug forfeiture statute is a complex business, $^{31}$ but it is possible to draw a broad outline. Under the statute, forfeiture occurs "upon commission of the act giving rise to forfeiture," with legal title passing immediately to the government. ${ }^{32}$ The "act giving rise to forfeiture" is a violation of the federal drug laws (21 U.S.C. $\S 801$ et seq.), whether actual or only intended.

The two most commonly invoked provisions of the forfeiture statute cover (1) property used, or intended to be used, to facilitate the commis-

27. See, e.g., United States v. 3639-2nd St., N.E., 869 F.2d 1093, 1096 (8th Cir. 1989) (single sale of two ounces of cocaine sufficient to justify forfeiture of home).

28. See, e.g., United States v. 4880 S.E. Dixie Highway, 838 F.2d 1558, 1559 n.1 (11th Cir. 1988) (forfeiting the "Manatee Resort").

29. See, e.g., United States v. 4492 S. Livoria Rd., 889 F.2d 1258, 1260 (2d Cir. 1989) (forfeiting 120 acres of land with a house, two barns, and a number of small buildings).

30. B. Drummond Ayres, Jr., 11 Held and Three Fraternities Seized in Drug Raids at U. of Va., N.Y. TIMEs, Mar. 23, 1991, § 1, at 1 (federal, state, and local law enforcenent sweep at the University of Virginia seized bags of marijuana, psychedelic mushrooms, LSD, and three frat houses).

31. For an in-depth treatment of practice under 21 U.S.C $\S 881$, see DAvID B. SMITH, Prosecution ANd Defense of Forferture Cases (1990). The existence of a looseleaf practice guide is evidence of the growing importance of drug forfeitures. For an understandably slanted coverage of forfeiture practice, see DRUG AGENTs' GUIDE, supra note 14. The manual is notable for its hard-line, pro-forfeiture attitude: "Once the judge determines that probable cause for forfeiture has been shown, the burden of proof (including the burden of producing evidence and the burden of persuasion) shifts to the defendant, or claimant!' Id. at 206 (citing 19 U.S.C. $\S 1615$ (1988)).

The Drug Agents' Guide also takes the Ninth Circuit to task for insufficient zeal in forfeiture cases.

Officials responsible for federal forfeitures within the Ninth Circuit ... should be aware they are governed by special rules not applicable to other jurisdictions. The power of pardon (remission) granted exclusively to the Executive Branch . . . has been assumed by the federal courts in these states. Moreover, federal judges in these states grant rehef to an owner based simply upon the owner's ignorance of the illegal use of his property. They are not requiring an owner to prove he met the highest standard of care in lending his property ....

$\ldots$

... Historically, the judicial rebellion against the forfeiture doctrine is alive and well

in the federal courts within the Ninth Circuit. Id. at 35 .

32. 21 U.S.C. $\$ 881$ (h) (1988). Subseetion (h) was enacted as part of the Comprehensive Crinie Control Act of 1984, Pub. L. No. 98-473, § 306, 98 Stat. 1837, 2051. However, courts recognized this presumption long before it was statutory, relying on early Suprenie Court forfeiture decisions. See, e.g., United States v. Henderson's Distilled Spirits, 81 U.S. (14 Wall.) 44, 57 (1871) (forfeiture "becomes absolute at the commission of the prohibited acts, and ... title from that inoment vests in the United States"). 
sion of a drug violation; ${ }^{33}$ and (2) the proceeds of a drug violation, whatever their form. ${ }^{34}$ Since there is no longer any state drug offense not covered by federal law, every drug offense under federal or state law, from simple possession to mass distribution, triggers the forfeiture statute. $^{35}$ Neither indictınent nor conviction of any offense is required, and acquittal at criminal trial is no defense. ${ }^{36}$

The forfeiture proceeding begins with the seizure of the res, which the government can accomphish in any of three ways. First, law enforcement can seize property pursuant to process issued by a district court under the rules of adıniralty. ${ }^{37}$ The second route is through the statutory mechanism prescribed by the federal forfeiture law for seizures without court-issued process. The statute authorizes seizure: (1) when property is discovered in a search incident to arrest or pursuant to a search warrant; ${ }^{38}$ and (2) when the Attorney General or his designee determines there is probable cause to beheve property is civilly forfeitable under 21 U.S.C. $\$ 881 .{ }^{39}$ A third important route is through federal "adoption" of seizures made by parties not authorized to act under federal law, such as state and local law enforcement agencies. ${ }^{40}$

33. 21 U.S.C. $\$ 881(a)(4),(6)$, (7) (1988). Examples under subsections (a)(4) and (a)(7) would be cars, boats, planes, and real property. The "facilitation" provision of subsection (a)(6) has been used to forfeit "seed money" (funds which are legitimately earned but intended to enable the commission of future drug offenses). See United States v. \$2,355.96, 647 F. Supp. 1460, 1463 (E.D. Mo. 1986).

34. 21 U.S.C. $\$ 881(\mathrm{a})(6)(1988)$. Note that the "proceeds" provision is not limited to cash or negotiable instruments. In one well-known case, only a pre-plea agreement prevented the government's successful forfeiture, under the "proceeds" provision, of a convicted drug trafficker's horse ranch, complete with horses. See United States v. D.K.G. Appaloosas, Inc., 829 F.2d 532, 534 (5th Cir. 1987), cert. denied, 485 U.S. 976 (1988). As the Department of Justice enthuses, "[t]he possibilities are almost limitless." DRUG AGENTS' GUIDE, supra note 14, at 121.

35. See, e.g., United States v. 303 W. 116 th St., 901 F.2d 288, 292-93 (2d Cir. 1990) (violation of New York state drug law sufficient basis for forfeiture under $\S 881$, since any "conduct which would violate chapter 13 , subchapter I of Titlc 21, regardless of whether that conduct results in a federal conviction," makes property subject to forfeiture). Subsection 881 (a)(7), the real property provision, requires that the triggering offense be punishable by imprisonment for greater than one year. However, since the federal drug laws have been strengthened, only simple possession falls under this exception. See 21 U.S.C. \$ 841 (1989).

36. See United States v. One Assortment of Eighty-Nine Firearms, 465 U.S. 354 (1984); United States v. Ward, 448 U.S. 242, 253 (1980).

37. 21 U.S.C. $\$ 881$ (b) (1988). For seizure under the rules of admiralty, see FED. R. CIV. P. SuPp. R. Certain Admir. \& Mar. Claims C(1)-C(3). To the extent that seizures under the admiralty rules are conducted through lawful process, they are not relevant to this Comment. But for a view that the admiralty mechanism circumvents the Fourth Amendment warrant requirement, see Michael Schecter, Note, Fear and Loathing and the Forfeiture Laws, 75 CoRNELL L. REV. 1151, $1169-73$ (1990).

38. 21 U.S.C. $\$ 881(\mathrm{~b})(1)(1988)$.

39. Id. $\S 881$ (b)(4). The statute also authorizes forfeiture when the United States has a lien on the subject property resulting from a prior judgment in its favor against the property, and when "the Attomey General has probable cause to believe that the property is directly or indirectly dangerous to health or safety." 21 U.S.C. $\$ 881$ (b)(2)-(3) (1988).

40. 19 U.S.C. $\$ 1619$ (1988); see United States v. Winston-Salem/Forsyth County Bd. of Edue., 902 F.2d 267, 269 n.1 (4th Cir. 1990) ("DEA adopts seizures by state or local law 
Once property is seized, the Justice Department may initiate forf ture proceedings against the property as prescribed by the custon laws. $^{41}$ If the seized property is valued at less than $\$ 100,000$ and $\left.t\right]$ property owner does not object, ${ }^{42}$ the property may be forfeited in c administrative proceedimg. ${ }^{43}$ Property of greater value is subject to judicial forfeiture proceeding. ${ }^{44}$

The rules in a judicial forfeiture proceeding are biased in favor of $t 1$ government. The government's advantage is due in part to the fiction "guilty property," discussed above in Section I.A, which enables forfe ture under $\S 881$ to proceed in rem. Since an action in rem is traditio. ally a civil proceeding, ${ }^{45}$ the action is conducted under the Federal Rul of Civil Procedure. As a result, the government has access to broad cir discovery, ${ }^{46}$ and may move for summary judgment. ${ }^{47}$

Another seeming advantage for the government in its quest for $\mathrm{tl}$ res is the lower evidentiary standard in civil suits-a preponderance , the evidence rather than proof beyond a reasonable doubt. ${ }^{48}$ The speci provisions of the drug forfeiture statute lessen the government's burds even further. The government must only show that there is probab

enforcement officials when it takes custody of seized property and treats the property as if DEA b made the initial seizure. DEA may then institute forfeiture proceedings in accordance with fede law."); DRUG AGENTS' GUIDE, supra note 14, at 145 ("Federal agents can adopt seizures made anyone.").

41. 21 U.S.C. $\$ 881(d)$ (1988). Relevant customs forfeiture laws are set forth at 19 U.S $\S \S 1594-1619$ (1988 \& Supp. II 1990).

42. Property owners commonly fail to contest judicial and administrative forfeit proceedings. The asset in question-generally cash-is often seized in close proximity to la amounts of controlled substances, so there is a considerable disincentive to stand up and cla ownership of the goods. See, eg., United States v. \$321,470.00 United States Currency, 874 F. 298, 299 (5th Cir. 1989) ("In this case the owner of $\$ 321,470$ in cash turned his back on what $\mathrm{m}$ have been pin inoney to him compared with the value of preserving his anonymity.").

43. 19 U.S.C. $\$ 1607$ (1988). Any claimant to the property who wishes to contest 1 forfeiture has twenty days from the publication of notice of the administrative proceeding. $T$ claimant must post a bond of $\$ 5000$ or $10 \%$ of the value of the forfeitable property, whichever lower, but not less than \$250. The case is then turned over to the Department of Justice for judic forfeiture proceedings. 19 U.S.C. $\$ 1608$ (1988). The procedures for administrative forfeiture : delineated in 21 C.F.R. $\$ \S 1316.71-.99$ (1991).

44. 19 U.S.C. $\$ 1610$ (1988).

45. " "Forfeiture of goods or their yalue and the payinent of fixed or variable sums of money : ... sanctions which have been recognized as enforceable by civil proceedings since the origir revenue law of 1789.' " United States v. D.K.G. Appaloosas, Inc., 829 F.2d 532, 541 (5th Cir. 198 (affirming civil nature of forfeitures under $\S 881$ ) (quoting Helvering v. Mitchell, 303 U.S. 391, 3! 400 (1938)) (emphasis added by court of appeals), cert. denied, 485 U.S. 976 (1988).

46. See FED. R. CIV. P. 26-37 (creating hiberal civil discovery system).

47. See, eg., United States v. One 1975 Mercedes 280S, 590 F.2d 196 (6th Cir. 1978) (affirmi summary judgment for government where claimant did nothing to rebut showing of probable caus

48. The preponderance of the evidence standard has been defined as "evidence which is greater weight or more convincing than the evidence which is offered in opposition to it; that evidence which as a whole shows that the fact sought to be proved is more probable than no Black's Law Dictionary 1182 (6th ed. 1990). Proof beyond a reasonable doubt requires tha prudent person would be "fully satisfied, entirely convinced, satisfied to a moral certainty; and [tl phrase is the equivalent of the words clear, precise and indubitable." Id. at 161. 
cause to believe that the property is subject to forfeiture, as either the proceeds or a facilitator of a drug violation. ${ }^{49}$

This is a minimal burden. The "probable cause" showing for forfeitures is similar to, and perliaps even lower than, the "probable cause" test apphed to all searches and seizures. ${ }^{50}$ One court has described the showing as follows: "The determination of probable cause in a forfeiture proceeding simply involves the question whether the information relied on by the government is adequate and sufficiently rehiable to warrant the belief by a reasonable person that the [res] was used to transport controlled substances." In everyday terms, this means that "the government can take a hoine without any more evidence than it normally needs to take a look inside." 52

Moreover, hearsay that would be inadmissible in a criminal proceeding is admissible to show probable cause in a forfeiture suit, based on an analogy between the probable cause showing required in forfeiture proceedings and the showing required for grand jury indictments. ${ }^{53}$ Probable cause is a question of law for a judge to decide, not a jury. ${ }^{54}$

Once the government shows probable cause for forfeiture, the statute shifts the burden of proof, for both production and persuasion, onto the claimant. In other words, once the government ineets its minimal burden, the claimant must prove that the property is not the government's. ${ }^{55}$ The Drug Agents' Guide to Forfeiture of Assets makes it clear:

This makes civil forfeiture cases significantly different than other civic [sic] actions. Once the Government establishes probable cause for forfeiture, as determined by the judge, the defendant must produce some evidence in defense of the property. If he does not, the judge must direct a verdict in favor of the Government. ${ }^{56}$

As a result of these statutory advantages to the government, it will not suffice for a property owner in a forfeiture suit to mount a strong defense. In a very real sense, she must mount a full-scale offense against the government in order to regain her property. ${ }^{57}$ There are two routes

49. 19 U.S.C. $\$ 1615$ (1988).

50. See United States v. One 56-Foot Yacht Named Tahuna, 702 F.2d 1276, 1281 \& n.3 (9th Cir. 1983).

51. Id. at 1282.

52. Andrew Schneider \& Mary P. Flaherty, Government Seizures Victimize Innocent, PITT. Press, Aug. 11, 1991, at A1.

53. See Tahuna, 702 F.2d at 1283-84.

54. 19 U.S.C. $\$ 1615$ (1988) ("[P]robable cause shall be first shown . . . to be judged of by the court ....").

55. Id. ("In all suits or actions ... brought for the forfeiture of any [res] ... where the property is claimed by any person, the burden of proof shall he upon such claimant; . . . Provided, [t]hat probable cause shall be first shown ....").

56. DRUG AGENTS' GuIDE, supra note 14, at 206.

57. Some commentators have suggested that this burden-shifting feature might be unconstitutional on due process grounds. See SMrTH, supra note 31, at 111.03 [8]; Schecter, supra note 37 , at $1164-66$. 
by which a property owner can contest a forfeiture. The first is to prove that the forfeiture statute was incorrectly invoked. This commonly ineans proving (a) that the property was not used or intended to be used to commit or facilitate a drug violation, or (b) that the asset is not traceable as the "proceeds" of a drug violation. ${ }^{58}$

Proceeding under the former theory usually means proving that no drug violation occurred or was intended, or that the property at stake was not sufficiently connected to the drug violation. ${ }^{59}$ The latter theory requires inore than a showing that there is a possible legitimate source of incoine for the cash or property; a claimant inust show by a preponderance of the evidence that the source of the income is in fact legitimate. ${ }^{60}$

The second inethod by which a claimant can attempt to contest forfeiture is to show that the property is excepted from forfeiture under a statutory provision or other legal primciple. For example, there is a statutory "innocent owner" exception to forfeitures: if a claimant can prove by a preponderance of the evidence that the act giving rise to the forfeiture was "committed or omitted without the knowledge, consent, or willful blindness of the owner," 61 then the forfeiture fails. Stolen conveyances and conveyances belonging to common carriers are simi-

58. In other words, the claimant inust prove that the property fits in none of the statutory classes enumerated in 21 U.S.C. $\$ 881(a)$, including (a)(4) (conveyances), (a)(6) (proceeds), and (a)(7) (real property).

59. There is a split in the federal circuits as to how inuch connection there must be between the asset and the proscribed act to warrant forfeiture under $\S 881$. The split is particularly significant in real property forfeitures under subsection $(a)(7)$, given the high stakes involved. Compare Ulited States v. Schifferli, 895 F.2d 987, 990 (4th Cir. 1990) (requiring a "substantial connection") with United States v. 916 Douglas Ave., 903 F.2d 490, 493 (7th Cir. 1990) (requiring "inore than an incidental or fortuitous connection to criminal activity" but less than a substantial connection), cert. denied, 111 S. Ct. 1090 (1991). Actions to forfeit proceeds under $\$ 881(a)(6)$ have generally been held to a "substantial connection" standard. But see United States v. $\$ 5,644,540.00$ in U.S. Currency, 799 F.2d 1357, 1362-63 (9th Cir. 1986) (declining to apply "substantial connection" standard to $\$ 881(\mathrm{a})(6))$.

60. See Uuited States v. $\$ 41,305.00$ in Currency, 802 F.2d 1339, 1344-45 (11th Cir. 1986) (affirming forfeiture where claimant only showed possible legitimate sources of incoine). The requirement that a claimant deinonstrate a legitimate source of incoine for the res has led to the telling of some ludicrous stories in open court. See, e.g., United States v. $\$ 280,505,655$ F. Supp. 1487 (S.D. Fla. 1986). In an attempt to explain the presence of some $\$ 280,000$ in the trunk of a friend's BMW, the clainant testified that he had sold an antique beer stein to a inysterious Mr. Ullrich of Switzerland. The clainant testified that he bought the stein for $\$ 8000$ in 1979 and then polished it, resulting in the appreciated value at the tinne of the sale in 1982. Mr. Ullrich could not be produced for trial, nor could the claimant give the buyer's full name or address, or any documentation of the sale. Id. at 1492. The claimant did not deposit the money in the bank right away because the banks were closed at the time of the sale, and he didn't deposit it the next day because he visited Busch Gardens, an amusement park, instead. Id. at 1493. In the court's opinion, "[t] he testimony regarding the Ullrich visit ... and the preceeding [sic] and following circumstances would do inore justice to a novel of intrigue than as support for a legitinate sale." Id.

61. 21 U.S.C. $\$ 881(\mathrm{a})(4)(C)(1988)$ (conveyances); see also id. $\S 881(\mathrm{a})(6)$ (proceeds or facilitating assets other than real property), (a)(7) (real property). 
larly exempted by the statute. ${ }^{62}$ There are also judicially created exemptions from forfeiture. For instance, if the government unduly delays filing a civil forfeiture action, claimants may seek dismissal. ${ }^{63}$ If a claimant's effort to contest forfeiture fails, he may still seek remission or mitigation of an adverse forfeiture judgment from the Attorney General. ${ }^{64}$ Clemency from law enforcement is not a promising prospect, however; in fiscal year 1990, the Justice Department forfeited $\$ 460$ million in assets and refunded $\$ 13$ million, just under three percent of the total. ${ }^{65}$

\section{Disposition of Forfeited Property}

Forfeited assets are distributed amongst a number of governmental offices. Initially, the Department of Justice takes custody of the forfeited property. ${ }^{66}$ Tangible, noncash property inay be retained by the Department for investigative use or transferred to "any Federal agency or to any State or local law enforcement agency which participated directly in the seizure or forfeiture of the property."67 If not retained or transferred, the property is sold. ${ }^{68}$ Proceeds from the sale, along with forfeited cash, are deposited in the Department of Justice Asset Forfeiture Fund after certain expenses are paid. ${ }^{69}$

The momes in this Fund are put to a number of uses. First, any federal, state, or local law enforcement agency that participated in the seizure of a forfeitable asset may request a portion of the resulting proceeds under the Department of Justice "equitable sharing" program. 70 This program is designed to promote cooperation between law enforce-

62. 21 U.S.C. $\S \S 881(\mathrm{a})(4)(B)$ (1988) (stolen conveyances), (a)(4)(A) (common carrier conveyances).

63. See United States v. $\$ 8,850$ in United States Currency, 461 U.S. 555 (1983). In this case, the Supreme Court denied the due process claim that the government's filing of the forfeitures suit was untimely, but it used the Sixth Amendment's speedy trial balancing test to evaluate the claim. "Undue delay" is potentially a major exception to drug forfeiture laws given the large amount of property in question. For example, 35,000 parcels of property awaited forfeiture filings at the beginning of 1991. Federal Seizure of Illegal Assets Nets Government \$1.5 Billion Since 1985, U.S.L.W. (Daily Edition), Feb. 4, 1991.

64. 21 U.S.C. $\$ 881$ (d) (1988) (assigning responsibility for mitigation under the customs laws (19 U.S.C. $\$ 1618$ (1988)) to the Attorney General or his designees).

65. Federal Seizure of Illegal Assets Nets Government \$1.5 Billion Since 1985, supra note 63.

66. 21 U.S.C. $\$ 881$ (e)(1) (1988 \& Supp. II 1990).

67. Id. $\S 881(\mathrm{e})(1)(\mathrm{A})(1988)$. Procedures for requesting transfer of forfeited property are laid out in the Attorney General's Guidelines on Seized and Forfeited Property, 52 Fed. Reg. 46,855 (1987) [hereinafter Guidelines]. Transfer of tangible property is governed by the same rules as cash transfers under the "equitable sharing" program, discussed infra.

68. 21 U.S.C. $\$ 881(\mathrm{e})(1)$ (B) (Supp. II 1990).

69. Id. $\S 881(\mathrm{e})(2)(\mathrm{B})(1988)$. The Fund was established in 1984 as part of the Comprehensive Crime Control Act of 1984, Pub. L. No. 98-473, § 310, 98 Stat. 1837, $2052-53$ (codified at 28 U.S.C. $\S 524(c)(1988))$.

70. 21 U.S.C. $\S 881(\mathrm{e})(1)(A)(1988) ; 19$ U.S.C. $\S 1616 \mathrm{a}(\mathrm{c})(1)(B)(1988)$ (as authorized by 21 U.S.C. $\$ 881$ (d) (1988)); see Guidelines, supra note 67, at 46,855 (discussing the Attorney General's authority to share forfeited property with local authorities). 
ment agencies engaged in the control of illegal narcotics by allowing them to share in the spoils of forfeiture. ${ }^{71}$ In determining the amount of the award, the Department must

assure that any property transferred to a State or local law enforcement agency ... .

(A) has a value that bears a reasonable relationship to the degree of direct participation of the State or local agency in the law enforcement effort resulting in the forfeiture, taking into account the total value of all property forfeited and the total law enforcement effort with respect to the violation of law on which the forfeiture is based. ${ }^{72}$

The Fund is also used for various law enforcement purposes, mcluding incidental expenses for forfeitures and imvestigations. ${ }^{73}$

From 1984 to 1988 , funds remaining at the end of the fiscal year were allowed to carry over into the next year, despite a provision for transfer of the funds to the Federal Bureau of Prisons for prison construction. ${ }^{74}$ Congress mcluded specific directives for use of the excess funds in the Anti-Drug Abuse Act of 1988. ${ }^{75}$ The Act requires that money remaining in the Fund at the end of fiscal year 1989 be transferred to the Bureau of Prisons, ${ }^{76}$ and the balance of funds im subsequent years be deposited into the newly created Special Forfeiture Fund. ${ }^{77}$ The a1nount deposited, not to exceed $\$ 150$ million, is then available to the Office of National Drug Control Pohicy for use in implementing the National Drug Control Strategy. ${ }^{78}$ The Special Forfeiture Fund received $\$ 109$ million for fiscal year 1990 and $\$ 128$ million for fiscal year $1991 .^{79}$ Thus far, the money has been used for corrections and special federal drug enforcement activities. ${ }^{80}$

71. "The Department intends to manage its asset forfeiture program in a manner designed to enhance this Federal, State, and local cooperation." Guidelines, supra note 67 , at 46,855 .

72. 21 U.S.C. $\$ 881$ (e)(3) (1988 \& Supp. II 1990). The Attorney General's guidelines clarify that "the governing factor to be considered is the time and effort contributed by each . . . agency ... " Guidelines, supra note 67 , at 46,857 . For a discussion of recent changes in the equitable sharing program and the law enforcement response, see infra Seetion II.C.

73. 28 U.S.C. $\S 524(\mathrm{c})(1)(\mathrm{A})(\mathrm{i})$-(ii) (1988) (expenses), (c)(1)(B)-(C) (awards to informants), (c)(1)(D) (payment of valid mortgages or liens at Attorney General's discretion), (c)(1)(E) (payment of remission or initigation of forfeited property), (c)(1)(F) (equipping forfeited vessels, vehicles, and aircraft conveyances for law enforcement use); (c)(1)(G) (purchase of contraband evidence).

74. 28 U.S.C. $\S 524(\mathrm{c})(1)(\mathrm{H})(1984)$, amended by statute cited infra note 75 .

75. Pub. L. No. 100-690, $\S 6073,102$ Stat. 4181,4323 (codified at 21 U.S.C. $\S 1509$ (1988)).

76. 28 U.S.C. $\$ 524(\mathrm{c})(1)(\mathrm{H})(1988)$. Two hundred eighty-one million, one hundred thousand dollars were ultimately transferred to the Bureau of Prisons at the end of fiscal year 1989. OFFICE of Nat'l Drug Control Policy, National Drug Control Strategy, Budget Summary $63 \mathrm{n.1}(1990)$.

77. Pub. L. No. $100-690, \S 6073,102$ Stat. 4181,4323 (1988) (codified at 21 U.S.C. $\S 1509$ (1988)).
78. Id.
79. Office of Nat'l Drug Control Policy, supra note 76, at 63 nn.2-3.
80. See supra note 4. 
II

\section{The Forfeitures Explosion AND ITS POLICY IMPLICATIONS}

\section{A. Real Money}

Although the civil drug forfeiture statute was ready for a war on drugs in 1978 with the passage of $\S 881(a)(6),{ }^{81}$ it would be several more years before the law began to reach its potential. It was not until 1984, with the passage of the Comprehensive Crime Control Act, ${ }^{82}$ that the use of forfeitures exploded onto the law enforcement scene. The Crime Control Act, which added numerous enhancements-the equitable sharing program, ${ }^{83}$ the real property forfeiture amendment, ${ }^{84}$ and the streamlined procedures for summary forfeiture, ${ }^{85}$ to name three-brought the forfeiture statute out of dormancy. ${ }^{86}$ Forfeitures have since increased at a rapid rate:

Disbursements to State and Local Law Enforcement

Forfeiture Receipts

Equitable Sharing

F.Y. 1985

F.Y. 1986

\$ 27.2

93.7

177.6

\$ 17.1

F.Y. 1987

207.3

46.8

F.Y. 1988

580.8

76.7

F.Y. 1989

459.6

157.3

F.Y. 1990

644.0

176.8

F.Y. 1991

$279.0^{87}$

81. Psychotropic Substances Act of 1978, Pub. L. No. 95-633, § 301(a), 92 Stat. 3768, 3777 (codified as amended at 21 U.S.C. $\$ 881$ (a) (1988)) (providing for forfeiture of "proceeds" of drug crime).

82. Pub. L. No. 98-473, tit. 2, 98 Stat. 1837, 1976-2194 (1984).

83. Id. $\S 318,98$ Stat. at $2055-56$ (ensuring the equitable transfer of forfeited property to state or local law enforcement agencies based on their contribution to acts leading to property seizure), repealed by Pub. L. No. 99-570, § 1863(b), 100 Stat. 3207, $3207-54$ (1984) (eurrent version at 19 U.S.C. $\S 1616 \mathrm{a}(1988))$.

84. Pub. L. No. 98-473, tit. 2, § 306, 98 Stat. 1837, 2050-51 (1984) (codified as amended at 21 U.S.C. $\S 881$ (e) (1988 \& Supp. II 1990)); see supra notes $24-31$ and accompanying text.

85. Pub. L. No. 98-473, tit. 2, § 311, 98 Stat. 1837, 2053-54 (1984) (codified as amended at 19 U.S.C. $\S 1607$ (1988)).

86. See, e.g. , Disposition of Seized Cash and Property: Hearing Before the Subcomm. on Federal Spending, Budget, and Accounting of the Senate Comm. on Governmental Affairs, 100th Cong., 2d Sess. 9 (1988) [hereinafter Disposition Hearing] (testimony of Mark M. Richard, Deputy Assistant Attorney General) ("Before passage of the 1984 Comprehensive Crime Control Act, we counted Federal forfeitures in the tens of millions of dollars. Today ... we count Federal forfeitures in the hundreds of millions of dollars.").

87. Federal Drug Forfeiture Activities, supra note 2, at 75 (fiscal years 1985-88); OFFICE OF NAT'L DRUg Control Policy, supra note 76, at 63 (fiscal ycars 1989-90); Department of Justice Reports $\$ 644$ Million in Illegal Assets Was Seized in Fiscal 1991, U.S. Newswire, Apr. 7, 1992, available in LEXIS, Nexis Library, Omni File (fiscal year 1991). The decrease in the forfeited amounts from 1989 to 1990 can be attributed to the one-time contribution of $\$ 221$ million by the Drexel Burnham ease to the fund in 1989. Office of Nat'l Drug Control. Policy, supra note 76 , at 65 . 
After more than $100 \%$ growth almost annually from 1985 to 1989 , the annual jump in total forfeiture amounts slowed somewhat. This effect probably has inore to do with resource constramts at the prosecutorial level than with a cooling of law enforcement interest in forfeitures. In addition to funds already forfeited, a backlog of 35,000 parcels of property with an estimated value of $\$ 1.3$ billion awaited forfeiture in February $1991 .{ }^{88}$

Nor has the bounty from forfeiture, distributed through the equitable sharing program, been limited to a select few police agencies; participation in the program is widespread. In 1990, 3,531 local police departinents and 1,270 sheriff's departments were transfer recipients under the prograin. ${ }^{89}$ This represents about $41 \%$ of the 11,800 local law enforcennent agencies with front-line responsibility in drug enforcement. ${ }^{90}$ More than $90 \%$ of the police agencies serving populations larger than 250,000 participated in the program and received equitable transfer funds that year. ${ }^{91}$

Participation in the program by police agencies seeins likely to continue to expand, given the benefits. Funds transferred under the equitable sharing program have typically doubled each year, and the proportion of transferred funds has risen froin $18 \%$ of the total forfeited ainount in 1986 to $43 \%$ in 1991. Further, since drug trafficking in the United States has been estimated at $\$ 100$ billion annually, ${ }^{92}$ there is httle reason to expect forfeited amounts to decline, and every reason to expect further growth.

\section{B. Easy Money: Asset Forfeitures and Law Enforcement Goals}

The allure of asset forfeiture has had a profound impact on the drug enforceınent strategies of participating law enforcennent agencies. Asset forfeiture not only holds out the proinse of added resources, ${ }^{93}$ but also provides a ready statistical ineasure of success in narcotics enforceinent. As a result, forfeiture has enierged as a tool for serving institutional interests in law enforcement, regardless of its effect on drug crime.

A common perception, both within and witlout law enforcenient agencies, is that a inajor obstacle to successful law enforceinent efforts is

88. Federal Seizure of Illegal Assets Nets Government $\$ 1.5$ Billion Since 1985, supra note 63 .

89. Mary Benanti, 8 Percent of Local Cops Fought War on Drugs Full-Time in 1990, Gannett News Service, May 10, 1992.

90. Almost 19,000 State, Local Law Officers Fight Drugs Full Time, U.S. Newswire, May 7, 1992, available in LEXIS, Nexis Library, Omni File.

91. Id.

92. Federal Drug Forfeiture Activities, supra note 2, at 119.

93. On the cover of the DRUG AGENTS' GUIDE, supra note 14, there are three bills of U.S currency. On each, the presidential head has been replaced by an opium poppy, a marijuana leaf, or coca leaves. 
lack of resources and the answer to the problem is more money. The drug war has exacerbated this situation:

There should be no attempt to disguise the fact that the expansion and reform of criminal justice efforts proposed [im the federal drug strategy] will require significant expenditures. ... [I]n the months and years to come, States and localities must allocate more funds to criminal justice, and the Federal Government must help. . . . If we are to build a national criminal justice system that meets the demands made on it by drug activity, this amount will have to be mcreased in the coming years. $^{94}$

To compound the problem, state and particularly local police, who are the major component of the anti-drug effort, are also at the levels of government with the fewest resources. ${ }^{95}$

Given law enforcement's resource constraints, asset forfeiture is an attractive option. Budgeting from general revenues can be a zero-sum game; a dollar more for law enforcement means a dollar less for some other prograin competing for the saine pool of money. The availability of forfeiture proceeds, on the other hand, depends only on law enforcement willingness to pursue them. Thanks to equitable sharing, a federal, state, or local law enforcement agency in need of additional funding need only pursue additional forfeitures.

Forfeitures are appealing at the institutional level for another reason. They are a way for law enforcement agencies to produce hard evidence that they are "winning" the drug war.

In the too-long absence of any real national consensus about the proper overarching goal of American drug policy, the only available measure of drug enforcement success has been statistical: so many thousands of arrests, so many tons of marijuana seized, so many acres of opium poppy and coca plants destroyed. ${ }^{96}$

Now another statistical measurement is available in the form of forfeiture proceeds. Forfeiture figures are impressive; they enable law enforcement to claim measurablc progress in the drug enforcement arena. Further, they are not subject to the sort of diminishing returns that drug use rates are; given the amount of potentially forfeitable property, forfeiture fignres are likely to increase at a much faster rate than drug use rates will decrease.

Forfeiture statistics are important within a law enforcement agency as well. Participating agents have an opportunity to show on paper that

94. Office of Nat'l Drug Control Policy, National Drug Control Strategy 31 (1989).

95. See Disposition Hearing, supra note 86, at 21 (statement of Sen. Lawton Chiles, D-Fla.) ("I hope you will appreciate that as desperate as Customs is, perhaps, for money, these State and local law enforcement officials are 10 times more desperate. And any asset money that they could get, any forfeiture money that they can get, of course they immediately put it into fighting crime on the streets and everything else they are doing.").

96. OfFice OF NAT'L Drug Control Policy, supra note 94, at 8. 
they are performing their jobs effectively and providing direct benefits to the agency. The positive effect on the reputation, rank, and career opportunities of law enforcenent agents who seize forfeitable funds for their agency is predictable. The people who staff law enforcement agencies also benefit materially from forfeited funds. They are the ones who will make use of the new items bought with forfeited funds and who will drive the fancy cars confiscated from drug offenders and transferred to the agency.

For law enforcement agents and agencies, the lure of asset forfeiture is strong, and the changes it has effected are significant. Far from being merely another weapon in the fight against drugs, forfeiture is shaping the core goals and policies of the fight itself. Asset forfeitures have become a legitimate alternative policy goal for law enforcement; apart from providing a means to the end of curbing drug crime, forfeitures have become an end in themselves. In other words, the reasoning behind the forfeiture law-that it was a good way to get at drug crime, with certain collateral benefits for participating law enforcement agencieshas been to some degree turned on its head, so that the motivation for law enforcement agencies to pursue forfeiture has become that it serves institutional imterests im self-perpetuation, with the possible collateral benefit of helping to fight drug crime.

This development is not a secret within law enforcement circles. The Drug Enforcement Agency entliuses:

[F]orfeitures produce vast amounts of revenue. Law enforcement has the potential, through forfeiture, of producing more income than it spends. With tax dollars becoming scarce, forfeiture holds the promise of improving drug enforcement and the method to use the assets of violators to support enforcement activities. . . . The long-range implications are enormous. ${ }^{97}$

The U.S. Department of Justice is equally forthright, listing " $[\mathrm{r}]$ evenue for the War on Drugs" as one of the three objectives of the federal forfeiture program. ${ }^{98}$ One high-ranking law enforcement official described the changes forfeiture has wrought on law enforcement in this way: "Increasingly, you're seeing supervisors of cases saying, 'Well, what can we seize?' when they're trying to decide what to investigate.... They're paying more attention to the revenues they can get ... and it's skewing

97. Federal Drug Forfeiture Activities, supra note 2, at 1.

98. "When the law enforcement and cooperative goals of the forfeiture program are successfully pursued, a natural byproduct is revenue which is pumped back into law enforcement so that forfeitures beget more forfeitures like a snowball rolling downhill." Oversight, supra note 5, at 123 (quoting Executive OfFICE for ASSET Forfeiture, U.S. DEP'T OF JUSTICE, FEderal Forfeiture of the Instruments and Proceeds of Crime: The Program in a Nutshell (1990)). 
the cases they get involved in."99

One way to understand that forfeiture has become a legitimate goal in itself is to listen to what law enforcement says; another way is to observe what law enforcement does. If law enforcement agencies pursue assets as an alternative goal, distinct froin other substantive goals such as criminal conviction, then it should follow that there will be inany instances when a forfeiture proceeding is not accompamed by a criminal trial of the property clainant. A recent study of forfeitures reveals this pattern. Reporters froin The Pittsburgh Press, who studied over 500 forfeiture proceedings during a ten-inonth period, found that eighty percent of the property claimants whose property was forfeited were never charged with any related criminal offense. ${ }^{100}$

Why does this happen? There may be insufficient evidence to charge the property owner with a criminal offense. Or it may be that criminal charges were neither intended nor desired; either the forfeiture itself is considered to be sufficient punishment, or puinshment of the property owner was never an objective. Whether there is insufficient evidence or insufficient desire to charge the claimant with the criminal offense underlying the forfeiture, it is clear that criminal conviction is simply one law enforceinent goal among many, rather than a necessary adjunct to forfeiture.

The law enforcement commumity's opposition to proposed changes in the federal forfeiture statute's "equitable sharing" provision reveals the seriousness with which it treats forfeiture. The federal equitable sharing program, designed to encourage cooperation between law enforcement agencies at all levels of government, was created by the Comprehensive Crime Control Act of 1984. ${ }^{101}$ Under the program, any federal, state, or local law enforcement agency inay apply to the Departnient of Justice for a share of the proceeds froin a forfeiture in which that agency participated. ${ }^{102}$ The program has been successful, resulting in the distribution of some $\$ 754$ million to state and local law enforcement agencies since $1985 .^{103}$

The program has been met with unbounded enthusiasin by state and local law enforcement. A 1987 survey conducted by the Department of Justice found that:

Ninety-six percent of sharing recipients beheve the sharing prograin has had a significant impact on cooperation between the agency and federal

99. Michael Isikoff, Drug Raids Net Much Valuable Property-and Legal Uproar, WAsH. Post, Apr. 1, 1991, at A1.

100. Schneider \& Flaherty, supra note 56, at A1.

101. Pub. L. No. 98-473, $\S 309,98$ Stat. 1837, $2051-52$ (codified as amended at 21 U.S.C. $\S 881(\mathrm{e})(1)$ (1988 \& Supp. II 1990)); see supra Section I.B.

102. Procedures to be used in the request and determination of equitable share are located in Guidelines, supra note 67.

103. See supra text accompanying note 87. 
law enforcement agencies. In addition, over 99 percent of respondents indicate that they plan to cooperate in joint investigations with federal agencies in the future in an effort to receive more shares. Further, 96 percent of respondents said the share received had imcreased law enforceinent resources for the agency, and 89 percent noted that the share had a significant impact on the agency's ability to fight crime. ${ }^{104}$

Law enforcement testimony before Congress is full of praise for the program:

The best tool you have provided us with is equitable sharing .... It has inade the difference in departments' level of cooperation. I'll give you an example ... . In 1986 the Regional Director of DEA came to iny office and asked us to start [drug interdiction activities]. At that time the leadership of the [highway] patrol did not really want to get involved because it was not a traditional function of their departınent, it was something new and different, and they really saw no interest in it until he started mentioning asset sharing. And then everybody's eyes lit up. ${ }^{105}$

Other eyes were highting up as well in the 1980s. State governments rapidly became aware of the revenue-generating potential in asset forfeitures, and subsequently passed or updated "baby" forfeiture laws. Many state statutes, however, do not funnel all or even most forfeiture proceeds back into law enforcement. ${ }^{106}$ For example, California law awards $20 \%$ of the forfeiture proceeds to the department of mental health, $10 \%$ to district attorneys, and $5 \%$ to nonprofit agencies which provide inforniation leading to seizures. ${ }^{107}$ Other states, such as Indiana and Missouri, direct that all the money be deposited in the state general fund. ${ }^{108}$ Thus, the federal law is a far better arrangement for state and local law enforcement agencies, since equitable sharing provides law enforcement directly with as much as $90 \%$ of the forfeited proceeds. ${ }^{109}$

Not surprisingly, this disparity between federal and state asset distribution tended to skew the practices of participatimg state and local law enforcement agencies. Some state and local law enforcement agencies were turning over seized assets to the Justice Department for "pure"

104. Federal Government's Forfeiture Programs Seized Cash and Forfeited Property Management: Hearing Before the Subcomm. on Federal Spending, Budget, and Accounting of the Senate Comm. on Governmental Affairs, 100th Cong., 1st Sess. 113-14 (1987) (statement of James Knapp, Deputy Associate Attorney General).

105. Federal Drug Forfeiture Activities, supra note 2, at 15 (statement of Joseph Dean, Department of Crime Control and Public Safety, North Carolina, on behalf of the National Governor's Association and the National Criminal Justice Association).

106. For a state-by-state analysis of forfeited assets disposition requirements, see id. at 210-14.

107. Id. at 210 (65\% of the proceeds go to participating law enforcement agencies).

108. Id. at 211-12.

109. See Guidelines, supra note 67 , at 46,857 ("If the Federal investigative effort is ten percent or less, the determining official will allocate ten percent to the Federal government to compensate for its administrative role and divide the participating agency shares from the remaining ninety percent."). Further, the Justice Department will only transfer assets if they will be credited to the budget of the state or local law enforcement agency, "resulting in an increase of law enforcement resources for that specific State or local agency." Id. 
adoption-federal adoption of assets seized by state or local agents without any federal assistance. The Justice Department would process the forfeiture, take its $10 \%$, and transfer the remaining $90 \%$ to state and local law enforcement coffers, thereby circumventing the dispositional requirements of state forfeiture laws.

California law enforcement came under particular congressional scrutiny for this practice. Through 1988, California law enforcement had received approximately half of all assets transferred through the federal equitable sharing program, due to their extensive use of the adoption procedure and despite a refurbished state forfeiture statute. ${ }^{110}$ In a 1988 House of Representatives hearing, the following exchange took place between Rep. Lawrence J. Smith (D-Fla.) and U.S. Attorney Joe Whitley:

MR. SMITH of Florida. Would you mind explaining why ... California should qualify for almost half of all the moneys being shared with State and local agencies in this country?...

MR. WHITLEY. In California ... the proceeds of the forfeited property are not going directly back to State law enforcement through their State laws .... Therefore, there are not as many incentives on the part of State and local law enforcement to use their own State procedures.

So, what we have in California is an inordinate amount of cases that are being pursued through the adoptive forfeiture process. That is, we receive a case which is in every respect a local case ... and we put our cover on it. ... [T] There is a surcharge of sorts for processing that adopted forfeiture case, of roughly 10 percent, which goes back into the [federal] fund. ... This is a very useful tool im California. ...

Mr. SMITH of Florida. ... Are you saying now that if you did not use the adoptive procedure, that there would be less inoney in the [state law enforcement] pot?

MR. WHITLEY. Yes, sir, in California particularly ....

MR. SMITH of Florida.... [W] hat you are telling me basically is that the Federal Government is coinplicit witl the law enforcement agencies in California in trying to in essence subvert the California [forfeiture law].... Is that what the Federal Government was set up to do, subvert the laws of California[?] ... . I cannot understand this at all. ${ }^{111}$

Congress responded to these concerns in the Anti-Drug Abuse Act

110. Federal Drug Forfeiture Activity: Hearing Before the Subcomm. on Crime of the House Comm. on the Judiciary, 100th Cong., 2d Sess. 94 (1988) (California received between $\$ 47$ million and $\$ 48$ million of the $\$ 117$ million available to state and local law enforcement agencies). By 1990, California law enforcement had received almost $\$ 150$ million in equitable sharing funds for fiscal years 1986-90, three times the amount of New York, its nearest competitor. Oversight, supra note 5, at 125-26. California is not the only state where law enforcement agents have engaged in this practiee. The Pennsylvania state police force became embroiled in a similar argument with the State Attorney General's office that lasted two years, resulting in a "treaty" between the two establishing how the spoils would be divided. See Schneider \& Flaherty, supra note 56, at D7.

111. Federal Drug Forfeiture Activity: Hearing Before the Subcomm. on Crime of the House Comm. on the Judiciary, supra note 110, at 94-95. 
of $1988^{112}$ by amending the forfeiture law to require that funds in the equitable sharing program not be transferred so as "to circuinvent any requirement of State law that prohibits forfeiture or limits use or disposition of property forfeited to State or local agencies."113

This change in the equitable sharing program was supposed to take effect at the end of fiscal year 1989, ${ }^{114}$ but state and local law enforcement agencies protested the change vigorously, calling for a repeal of the ainendment, or at the very least, its postponeinent. Law enforceinent officials worked to send a message to Congress that unless the amendment was repealed, not only would state and local agencies lose financial incentive to pursue forfeitures, but the highly touted war on drugs would suffer. One witness before a congressional committee described the depth of the anxiety among law enforcennent officials:

The one biggest topic of conversation in ... law enforcement since the 1988 amendinent has been this:

I've heard from the chiefs' association, the sheriff's association. ... [T] he Attorney General of the State, my Governor, and everybody else I've talked to that has anything, any interest, in law enforcement is scared to death that it's going to be taken away. ...

The assets that we seize, the money that we can turn into pure law enforcement, makes a difference in my State. It really does. It makes a difference to sheriffs and to police chiefs.

But mostly it's the cooperation that comes from it and the good that we are able to do in getting dope off the streets and the dopers tied up, financially as well as criminally.

If you take the profit out of it, you'll do away with it. This is the thing that takes the profit out of it....

If it is not repealed, the only people that are going to win, in my judgment, in my State, are going to be the drng traffickers. ${ }^{115}$

Faced with pressure froin the National Governor's Association, ${ }^{116}$ the National Criminal Justice Association, ${ }^{117}$ the International Association of Chiefs of Police, ${ }^{118}$ and numerous individual law enforceinent agencies, Congress bowed. In 1989, Congress postponed the offending prohibition on circumvention of state laws until the end of fiscal year

112. Pub. L. No. $100-690,102$ Stat. 4181.

113. Id. $\S 6077$, 102 Stat. at $4324-25$, repealed by Pub. L. No. 101-189, $\S 1215,103$ Stat. 1352, 1569 (1989) (codified at 21 U.S.C. $\$ 881(\mathrm{e})(3)(B)$ (Supp. II 1990)).

114. $I d$.

115. Federal Drug Forfeiture Activities, supra note 2, at 16-17 (statement of Joseph Dean, Department of Crime Control and Public Safety, North Carolina, on behalf of National Governor's Association and the National Criminal Justice Association) (emphasis added).

116. Id.

117. Id.

118. Id. at 160-68 (statement of Charles Reynolds, President of the International Association of Chiefs of Police). 
$1991,{ }^{119}$ and replaced it with this meek statement: “(3) The Attorney General shall assure that any property transferred to a state or local law enforcement agency ... (B) will serve to encourage further cooperation between the recipient State or local agency and Federal law enforcement agencies." 120 It is by no means certain that the ainendment will take effect as planned in 1992, simce forfeitures contimue to mushroom, along with the financial stakes of state and local law enforcement. ${ }^{121}$

Two insights regarding the innortance of asset forfeiture may be drawn from the battle over circumvention requirements. The first is that there was law enforcement circumvention of disposition requirements at all. If the money was unimportant to law enforcement, and forfeitures were just another effective way to diminish drug crime, there would have been no circumvention of state requirenents $\mathrm{m}$ the first place. Instead, law enforcement was willing to go to considerable lengths to avoid state law requirements and take the larger share of forfeited funds.

The second insight is implicit in the argument that law enforcement agencies made to Congress in their effort to repeal the anti-circumvention requirement. If there was no equitable sharing, agencies claimed, there would be few forfeitures. The foundation of this argument is that there is no good reason for law enforcement agencies to pursue forfeiture apart from the financial benefits. The original reasoning underlying drng forfeiture-that it would remove the economic appeal of drug crimewould presumably dictate that forfeiture be pursued regardless of collateral benefits to seizing agencies. The unavoidable conclusion is that the original purpose of forfeiture has been eclipsed by, or subordinated to, the benefits forfeiture brings to seizing agencies.

Of course, this development was not unanticipated by the creators of the forfeiture law.

By law, the Congress must reduce the growth in Federal spending but at the same time we must accelerate our antidrug offensive if we are ever to rid the Nation of the drug scourge.

Asset forfeiture certainly was intended in some areas to fill that funding lag, particularly with the local law enforceinent agencies. ${ }^{122}$

Given that participatimg law enforcement agencies have changed their goals, the question becomes whether they have changed their practices. The police practice most obviously identified with the pursuit of forfeiture is property seizure-the first step in forfeiture. This is a troubling connection, smce adherence to Fourth Amendment standards for search and seizure has long been one of law enforcement's largest fail-

119. Pub. L. No. 101-189, § 1215(b), 103 Stat. 1352, 1569 (1989) (to be codified at 21 U.S.C. § 881(e)(3) (1988 \& Supp. II 1990)).

120. 21 U.S.C. \& 881(e) (1988 \& Supp. II 1990).

121. See supra text accompanying note 87 .

122. Federal Drug Forfeiture Activities, supra note 2, at 3 (statement of Rep. Larkin Smith, RMiss.). 
ures, particularly in the narcotics arena, and a matter of concern for courts and legislatures for decades. The shift in law enforcenent goalsfrom pursuing criminals to pursuing assets-calls for re-evaluation, and perhaps reformulation, of the inechanisins designed to deter police violations of Fourth Amendment standards.

\section{III}

\section{DETERRENCE OF LAW ENFORCEMENT MISCONDUCT IN VIOLATION OF THE FOURTH AMENDMENT}

\section{A. What Is Deterrence?}

Like forfeiture, the concept of deterrence can be traced back at least to biblical times. ${ }^{123}$ Put simply, deterrence inay be understood as shorthand for the fundamental notion that people respond to incentives and disincentives, a theory with both a long history and few articulate opponents. Deterring pohice violations of Fourth Amendment standards, then, would appear to be nothing more than a special case of atteinpting to reduce undesirable behavior by attaching unpleasant consequences to that behavior. However, the special nature and role of law enforcement agencies make the study of deterrence in this context a good deal more than a special application of price theory.

Franklin E. Zimring and Gordon Hawkins have described the basic deterrence model as follows: a threatening agency issues a legal threat, with the objective of reducing the instances of a given threatened behavior, through the threatened audience's fear of the threatened consequences. ${ }^{124}$ In the standard paradigm of the criminal law, the threateuing agency is the state, which issues its legal threat, the criminal statute. The statute defines a threatened behavior-say, burglary-and the threatened consequences, which are fines and/or imprisonment. The audience at which this threat is aimed is the general populace, or rather those ineinbers of the populace considering committing a burglary.

An imagimed application of this model to police violations of Fourth Amendment standards is equally straightforward. The threatened behavior is failure to adhere to articulated standards of Fourth Amendment activity. The threatened audience includes law enforcement agencies and their einployees. The identity of the threaten-

123. When a malicious witness comes forward to give false evidence against a man, and the two disputants stand before the LORD, before the priests and the judges then in office, if, after careful examination by the judges, he be proved to be a false witness giving false evidence against his fellow, you shall treat him as he intended to treat his fellow, and thus rid yourselves of this wickedness. The rest of the people when they hear of it will be afraid: never again will anything as wicked as this be done among you.

Deuteronomy 19:16-22.

124. Franklin E. Zimring \& Gordon Hawkins, Deterrence: The Legal Threat in Crime Control 70 (1973); see also Franklin E. Zimring, Perspectives on Deterrence 1 (Nat'l Inst. of Mental Health, Public Health Service Pub. No. 2056) (1971). 
ing agency is a variable; the only constant is that it must be some agency with sufficient authority to threaten the law enforcement audience. The form of the threat is similarly variable; one can imagine any number of threatened consequences, up to and including criminal penalties against the actors, for engaging in the threatened behavior.

Deterrence is usually conceptualized as an aim or an outcome; that is, in terms of reducing or eliminating instances of the undesirable behavior, or in terms of the end product of diminished instances of behavior. ${ }^{125}$ But it nay be inore useful to think of deterrence neither as an aim nor an outcoine, but rather as a process. This Section briefly explores how deterrent inechanisms operate. ${ }^{126}$

The simplest inodel of deterrence envisions a perfectly informed and rational individual calculating and weighing the varying costs and benefits of a given course of action, much like "a dispassionate custoiner peering at a price hist in search of bargains." 127 The legal threat is designed to be a heavy weight on the cost side of the equation.

Modern writers have recognized that the process of deterrence need not be so explicit in order to work; legal threats have a number of less direct effects on threatened groups. The first broad category of indirect effects may be called the inoral or educative effect of pumshment, which has at least three aspects. ${ }^{128}$ The simplest aspect is that the "association of forbidden behavior and bad consequences may lead individuals to view the behavior itself as bad." 129 The knowledge that people who engage in the threatened activity are treated badly would lead the threatened audience to associate the activity with badness generally, and thus to the conclusion that the activity is simply wrong. ${ }^{130}$ The next moral or educative effect of punishment is that it sends the institutional message that the legal system disapproves of the threatened behavior, and the perceived inoral authority of that system influences the behavior of the threatened audience. ${ }^{131}$ The thought process could be represented as: "the institutions I respect view this behavior as wrong; therefore, I should consider this behavior wrong." 132 The final educative or moral effect of punishment is what Professor Andenaes has called the "moral eye-opener"-

125. Z1MRING, supra note 124 , at 3 .

126. For a broader discussion of the deterrent process and the factors affecting the deterrent outcome, see Johannes Andenaes, Punishment and Deterrence (1974); ZimRIng \& HawKINS, supra note 124, at 70-224.

127. ZIMRING, supra note 124, at 3; see also ZIMRING \& HAwKINS, supra note 124, at 75-77.

128. ZIMRING, supra note 124, at 4-5; ZIMRING \& HAwKINS, supra note 124, at 77-84; Johannes Andenaes, The Moral or Educative Influence of Criminal Law, in LAW, JUSTICE, AND THE INDIVIDUAL IN SOCIETY 50-59 (June L. Tapp \& Felice J. Levine eds., 1977).

129. ZIMRING \& HAWKINS, supra note 124 , at 81 .

130. Id.

131. Id. at 81-83; Andenaes, supra note 128, at 53-54. Andenaes calls this effect "punishment as authoritative statements about badness." Id.

132. ZIMRING \& HAWKINS, supra note 124 , at 82. 
persons who engage in the undesirable activity may not realize the moral weight of their conduct, and the threat of punishment opens their eyes to this fact. ${ }^{133}$ In short, the very existence of a threatened punishment causes them to consider the socially deleterious qualities of the threatened behavior, and nuay lead thein to reject the activity as wrong. ${ }^{134}$

The second nonexphicit deterrent effect of the threat of punishment can be described as a process of habituation. ${ }^{135}$ The raw threat of punishment provides the initial inipetus for the threatened audience to comply with the law. But, as comphance becomes custoniary the need for external sanctions falls away, and the threatened behaviour disappears from the audiences' range of conscious choice, creating a pattern of "habitual lawfulness." 136

Third, the threat of punishment shows that "the legal systen is serious in its attenipt to prohibit criminal behavior: it is the "convincer." "137 By showing that the law neans what it says, the legal threat creates respect for that law. Conversely, when threatened behavior goes unpunished, there is a "direct challenge to the authority behind the law."138

Fourth, the threat of punishment nay serve as a rationale for conformity to the law. ${ }^{139}$ The threatened audience nuay need or even desire sonie external reason to counterbalance internal impulses towards the conimission of the disapproved behavior. The threatened consequences nay provide such a reason, thus engendering lawful behavior.

Whether alone or in combination, these effects of the legal threat work to create a deterrent outconie ranging from nonexistent to significant levels of desistance. One legal threat often estiniated to fall very near the low end of the scale is the so-called "exclusionary rule."140

\section{B. Deterrent Sanctions: The Exclusionary Rule and Civil Forfeitures}

\section{The Exclusionary Rule Debate}

The creation of an external sanction to diminish instances of law enforcenient agents' violation of Fourth Amendment standards is not a new project for the law. Indeed, since United States v. Calandra, ${ }^{141}$ the deterrence of such violations has been the predominant purpose of the

133. Andenaes, supra note 128, at 53.

134. ZIMRING \& HAWKINS, supra note 124, at 83; Andenaes, supra note 128, at 53.

135. ZIMRING, supra note 124, at 5; ZIMRING \& HAWkINS, supra note 124, at 84-87; Johannes Andenaes, The General Preventive Effects of Punishment, 114 U. PA. L. REv. 949, 951 (1966).

136. Andenaes, supra note 135 , at 951 .

137. ZimRING \& HAWKINS, supra note 124, at 87; see also Andenaes, supra note 135, at 950.

138. ZIMRING, supra note 124, at 6.

139. Id.; ZIMRING \& HAWKINS, supra note 124, at 88.

140. See, eg., Dallin H. Oaks, Studying the Exclusionary Rule in Search and Seizure, 37 U.

CHI. L. Rev. 665 (1970).

141. 414 U.S. 338 (1974). 
exclusionary rule in criminal cases. ${ }^{142}$ Broadly stated, the rule requires that evidence seized in violation of the Fourth Amendment be suppressed at the criminal trial of a person entitled to assert Fourth Amendment rights. ${ }^{143}$

The rule's underlying assumption is that the threat of suppression will act as a deterrent against law enforcement violations of Fourth Amendinent search and seizure standards because criminal prosecution is a goal of law enforceinent. "Pohice officers and prosecuting officials are primarily interested im convicting criminals. Given the exclusionary rule and a choice between securing evidence by legal rather than illegal means, officers will be impelled to obey the law thenselves since not to do so will jeopardize their objectives." 144 On the basis of this rationale, the Supreme Court has come to apply the rule only when it finds that the deterrent effect on Fourth Amendinent violations outweighs the social cost of inposing the rule. ${ }^{145}$ Due in no small part to this formulation, the exclusionary rule has lately fallen on hard times. The Supreme Court has narrowed the application of the rule at practically every turn, ${ }^{146}$ and the call for a legislative alternative grows louder each year. ${ }^{147}$

At least two important pohicy arguments challenge the propriety of the rule. First, the exclusionary rule inay impose excessive costs on society by excluding evidence that is probative of a crime. The inost obvious example is a case where excluded evidence is the only evidence that would appropriately persuade a fact-finder to convict, or would make a difference to the fact-finder at the margin. In such a case, the rule imposes a social cost by allowing a guilty criminal to go free. The second arguinent against the rule is even more basic. Regardless of the social cost, the rule simply has little or no deterrent effect on law enforcement practices. The fear that evidence inay not be adinissible at trial is too remote a concern to coinpel law enforceinent agents to respect the boundaries of the Fourth Amendinent. ${ }^{148}$

While both of these criticisins merit consideration, the second criticisin is more serious. If the exclusionary rule generates siguificant levels

142. Id. at 347 .

143. See Jerome H. SKolnick, JUstice Without Trial: LAW ENForcement in DEMOCRATIC SOCIETY 211 (1966).

144. People v. Cahan, 282 P.2d 905, 913 (Cal. 1955) (Traynor, J.).

145. See INS v. Lopez-Mendoza, 468 U.S. 1032, 1041 (1984); United States v. Janis, 428 U.S. 433, 453-54 (1976) (the rule does not require the exclusion from federal criminal proceedings of evidence seized by state police illegally but in good faith).

146. See, e.g., Lopez-Mendoza, 468 U.S. at 1042-43 (rule not applicable in civil deportation proceedings); United States v. Leon, 468 U.S. 897, 913 (1984) (rule not applicable to "good faith" violations of the Fourth Amendment); United States v. Jacobsen, 466 U.S. 109, 113 (1984) (rule not applicable to private-party searches subsequently reported to police); Rakas v. Illinois, 439 U.S. 128, 134 (1978) (narrowing standing to invoke protection of the rule).

147. See, e.g., H.R. CONF. REP. No. 405, 102d Cong., 1st Sess. (1991).

148. For a general summary of this argument, see Oaks, supra note 140. 
of Fourth Amendment compliance, then the debate over the rule concerns only the poitical calculus which balances the need for freedom of information in the adversary process against the enforceinent of Fourth Amendment values. If, on the other hand, the exclusionary rule is incapable of safeguarding the constitutional rights it was designed to protect, then no justification is sufficient to invoke the rule, as any cost is too high when there is no countervailing benefit.

Ultimately, we need not determine the efficacy of the exclusionary rule where criminal prosecution is the goal to understand the impact of the exclusionary rule where forfeiture is the goal. Even assuming the exclusionary rule does generate significantly high levels of compliance with Fourth Amendinent standards in the former situation, the rule can never achieve similar levels of effectiveness in the latter situation. In fact, it is questionable whether the rule can have any deterrent effect at all im forfeiture cases. Designed primarily for criminal proceedings, the exclusionary rule can only generate a deterrent effect on police conduct in pursuit of forfeiture to the extent that it functions in forfeiture proceedings in a manner similar to its original design. It does not.

The designed function of the exclusionary rule is to present law enforcement agents with a choice-eitler they act in conformity with Fourth Amendment standards, or they put in jeopardy the achievement of some substantive goal. Traditionally, it was assumed the primary substantive goal of law enforcement was to apprehend and eventually convict offenders. As seen, for law enforcement agencies participatimg im forfeiture, the goal of conviction may now be coextensive with, and even eclipsed by, the desire to forfeit tainted property.

To have any deterrent effect in the forfeitures context, the exclusionary rule must offer law enforceinent agents a choice similar to that in criminal prosecutions. Agents inust know that either they comply with Fourth Amendment standards or they endanger their goal of gaiming the assets in question (the ranch, the casl, or the plane). As currently applied in the forfeitures context, the exclusionary rule does nothing of the kind.

\section{Parallel Doctrine, Skewed Results}

Victorino Hernandez purchased a one-way ticket from Buffalo, New York, to New York City. ${ }^{149}$ At a routine security checkpoint in the Buffalo airport, X-ray scanners revealed what appeared to be a large amount of cash in Hernandez' briefcase. Security officials asked Hernandez if they could look inside the case; Hernandez consented, and the agents found about $\$ 38,000$, most of it in denominations of $\$ 20$ or less. Drug Enforcement Agency agents were called to the scene.

149. United States v. $\$ 37,780$ in U.S. Currency, 920 F.2d 159, 160 (2d Cir. 1990). 
In response to the agents' questions, Hernandez indicated that the money came from his mother in the Dominican Republic and was to be used to open a restaurant in New York City. Hernandez claimed to be in the employ of the $D E A$, and claimed to have no prior arrests on drug charges. ${ }^{150}$ The agents did not arrest Hernandez, but they seized the currency. A post-seizure investigation revealed that Hernandez did not work for the $D E A$, local law enforcement authorities were investigating him for possible drug violations, and confidential informants tied him to drug trafficking. The government then initiated forfeiture proceedings against the currency. Hernandez responded with a motion for summary judgment claiming there had not been probable cause to seize the cash. ${ }^{151}$ The district court judge agreed that probable cause was lacking, because the federal agents had seized the currency from Hernandez "simply because he possessed it and because federal agents did not like his proffered explanation for such possession." ${ }^{\text {"152 }}$ In light of this Fourth Amendment violation, and a careful consideration of the application of the exclusionary rule to civil forfeitures, the district court made its ruling on the motion for summary judgment.

During the exclusionary rule's "expansive" phase, the Supreme Court endorsed the apphication of the exclusionary rule to civil forfeiture proceedings. In. One 1958 Plymouth Sedan v. Pennsylvania, ${ }^{153}$ state liquor enforcement police stopped an automobile that seemed to be "riding low." After questioning the owner, the officers searched the car and found thirty-one cases of contraband hquor, which they seized along with the car. The state filed suit under a state statute similar to 21 U.S.C $\S 881(\mathrm{a})(4)$, providing for conveyance forfeiture. ${ }^{154}$ At trial, the car owner filed for dismissal "on the ground that the forfeiture of the automobile depended upon the admission of evidence illegally obtained in violation of the Fourth Amendment." 155 The trial court agreed with the claimant, but the imtermediate appeals court and the state supreme court did not, holding that the exclusionary rule applied only to criminal proceedings. ${ }^{156}$

The Supreme Court reversed in a unanimous decision, holding that

150. Id. at $160-61$.

151. Id. at 161 .

152. Id.

153. 380 U.S. 693,694 (1965).

154. "No property rights shall exist in any liquor, alcohol or malt or brewed beverage illegally manufactured or possessed, or in any still . . . vehicle, boat, vessel, animals, or aircraft used in the illegal manufacture or illegal transportation of liquor, alcohol or malt or brewed beverages, and the same shall be deemed contraband and proceedings for its forfeiture to the Commonwealth may, at the discretion of the board, be instituted in the manner hereinafter provided."

Id. at 694 n.2 (quoting PA. STAT. ANN., tit. 47, § 6-601 (1964)).

155. Id. at 694-95.

156. Id. at 695 . 
the rule did apply to "forfeiture proceedings of the character involved here."157 Relying on early precedent, the Court noted that a forfeiture proceeding is "quasi-criminal" despite its civil form, since it is designed to punish violations of the criminal law. ${ }^{158}$ The Court distinguished a forfeitable auto from other types of contraband:

There is nothing even remotely criminal in possessing an automobile. It is only the alleged use to which this particular automobile was put that subjects [the owner] to its possible loss. And it is conceded here that the [state] could not establish an illegal use without using the evidence resulting from the search which is challenged as having been in violation of the Constitution. ${ }^{159}$

The Court concluded that since forfeiture is a penalty for a violation of the law, it would be "anornalous" to admit illegally obtained evidence in a forfeiture proceeding, but not a criminal trial, when the punishment in a forfeiture proceeding could be greater than in a criminal trial. ${ }^{160}$

Relying on Plymouth Sedan, courts hearing actions under 21 U.S.C. $\S 881$, the modern drug forfeiture statute, have uniformly held that the exclusionary rule is applicable in asset forfeiture proceedings. ${ }^{161}$ The rule's formal application in forfeiture proceedings has been exactly parallel to its traditional application in criminal proceedings. The rule requires evidence seized in violation of the Fourth Amendment to be suppressed upon a proper inotion by a person entitled to assert the rule's protection.

What inay be termed "parallel application" does not work parallel results, however. Tailored to fit the inodel of the criminal trial and handed down to the forfeiture proceeding, the rule fits poorly on its new wearer. Divorced froin any consideration of the functional differences between the two proceedings, the blind application of the rule in the saine nianner in both works different effects in each. At the sanie time they have found the rule to apply to forfeiture proceedings, courts liave also uniformly lield that the illegal seizure of the res does not bar its eventual forfeiture. ${ }^{162}$ That is, the admission of illegally seized evidence is barred by Plymouth Sedan, but the government nray still use untainted

157. Id. at 696 .

158. Id. at 700 .

159. Id. at 699.

160. Id. at 701 .

161. See, eg., Floyd v. United States, 860 F.2d 999, 1006-07 (10th Cir. 1988); United States v. $\$ 84,000$ U.S. Currency, 717 F.2d 1090, 1094 (7th Cir. 1983), cert. denied, 469 U.S. 836 (1984); United States v. \$22,287, United States Currency, 709 F.2d 442, 446 (6th Cir. 1983); United States v. One 1977 Mercedes Benz, 450 SEL, 708 F.2d 444, 447 (9th Cir. 1983), cert. denied, 464 U.S. 1071 (1984); United States v. \$88,500, 671 F.2d 293, 297 n.6 (8th Cir. 1982); United States v. One 1979 Mercury Cougar XR-7, 666 F.2d 228, 230 (5th Cir. 1982).

162. See, eg., United States v. 4492 S. Livonia Rd., 889 F.2d 1258, 1265 (2d Cir. 1989); United States v. U.S. Currency $\$ 31,828,760$ F.2d 228, 230 (8th Cir. 1985); \$22,287 United States Currency, 709 F.2d at 446; United States v. "Monkey," 725 F.2d 1007, 1011 (5th Cir. 1984); One 1977 Mercedes Benz, 450 SEL, 708 F.2d at 450. 
evidence to prove that the property is subject to forfeiture. ${ }^{163}$ This aspect of the exclusionary rule's application to forfeitures is structurally consistent with the rule's application in criminal proceedings. It has always been true that if the goverumient can prove its criminal cliarge beyond a reasonable doubt witlout the use of tainted evidence, then a conviction will lie.

It is far from functionally consistent, lowever. The premise of the exclusionary rule is that the exclusion of evidence puts at risk the prosecution's ability to meet the burden of proof in a criminal trial, thus mcreasing the seriousness of the consequences of law enforcement's breach of Fourth Amendment standards. The special features of the forfeiture statute undermine this premise, and thus its presumed effectiveness.

Under 21 U.S.C. $\$ 881$, the government need only make a minimal showing of probable cause-far lower than the reasonable doubt standard in a criminal proceeding - to shift the burden of proof onto the claimant. ${ }^{164}$ The police can meet the probable cause standard to secure a searcl warrant witl as hittle as a signed affidavit from an undisclosed informant, so the admissibility of the fruits of an illegal search at a forfeiture proceeding is often not a great concern. ${ }^{165}$ Moreover, probable cause can turn on purely circumstantial evidence, ${ }^{166}$ and even hearsay. ${ }^{167}$ The government is furtler advantaged by the fact that evidence obtained after seizure is as admissible as evidence obtained before seizure, ${ }^{168}$ so that groundless seizures may be subsequently "cured."

Post-seizure evidence is admissible because the "probable cause" required in a forfeiture proceeding is only probable cause to believe that the res was used to commit a drug violation. ${ }^{169}$ This is analytically dis-

163. See, e.g., One 1977 Mercedes-Benz 450 SEL, 708 F.2d at 450 ("[A]ny evidence which is the product of an illegal search or seizure must be excluded at trial, but . . . forfeiture may proceed if the Government can satisfy the requirements for forfeiture with untainted evidence.") This is by no means incompatible with Plymouth Sedan, in which the Court reversed the forfeiture only because the state "could not establish an illegal use without using the evidence resulting from the [allegedly illegal] search." Plymouth Sedan, 380 U.S. at 699.

164. See supra Section I.C.

165. See Illinois v. Gates, 462 U.S. 213, 230-36 (1983).

166. See e.g., $\$ 31,828,760$ F.2d at $230-31$; United States v. $\$ 93,685.61$ in U.S. Currency, 730 F.2d 571, 572 (9th Cir.), cert. denied, 469 U.S. 831 (1984).

167. See United States v. One 56-Foot Motor Yacht Named Tahuna, 702 F.2d 1276, 1282 (9th Cir. 1983) (basing admissibility of hearsay on analogy of probable cause showing to grand jury indictment).

168. See, e.g., United States v. $\$ 91,960,897$ F.2d 1457, 1462 (8th Cir. 1990); United States v. "Monkey," 725 F.2d 1007, 1011 (5th Cir. 1984); United States v. One 1978 Mercedes Benz, FourDoor Sedan, 711 F.2d 1297, $1302-03$ (5th Cir. 1983); United States v. \$36,000, 1991 U.S. Dist. LEXIS 5079 (D. Kan. Mar. 29, 1991); United States v. \$252,671.48 in U.S. Currency, 734 F. Supp. 254, 257 (N.D. Tex. 1990); see also SMITH, supra note 31, at ๆ 11.03[6]. But see United States v. All Monies (\$637,944.57) in Account No. 29-0101-62 in the Name of Abusada, 746 F. Supp. 1432, 1438 n.6 (D. Haw. 1990).

169. 21 U.S.C. $\$ 881$ (1988 \& Supp. II 1990). 
tinct from the issue in a Fourth Amendment suppression motion, which is whether probable cause existed for the seizure at the time of the seizure. When a law enforcement agent seizes property im violation of the Fourth Amendment and a forfeiture proceeding follows, a court will presumably suppress the fruits of the search. However, the government may use additional evidence gathered after the seizure to show that the asset was used to facilitate a drug violation. So, even if the evidence supporting the original seizure was shight, in aggregate with the subsequently discovered evidence, it may well satisfy the probable cause standard.

The opportunity these "two bites at the apple" provide for law enforcement agencies is predictable both from a psychological and practical standpoint. In a situation where the constitutional validity of a considered law enforceinent action is im doubt, there is hittle deterrent, and every incentive, to proceed with seizure. If law enforcement agents commit constitutional error, they have a chance to compensate for that fact and still forfeit the property.

\section{Further Dysfunctional Results of Parallel Rule Application}

The formalistic application of the exclusionary rule to forfeiture proceedings threatens to generate even greater dysfunctional effects than those discussed im the previous Section. A recent Supreme Court decision either seriously misreads prior forfeiture precedent or represents a logical extension of parallel apphication doctrime; whatever its origin, its reasoning threatens to eviscerate the exclusionary rule in forfeiture cases.

In INS v. Lopez-Mendoza, ${ }^{170}$ the Supreine Court held the exclusionary rule inapplicable in administrative deportation hearings. In a footnote, the Court noted that '[t]he 'body' or identity of a defendant or respondent ... is never itself suppressible as a fruit of an unlawful arrest, even if it is conceded that an unlawful arrest, search, or interrogation occurred. . . . A similar rule apphies in forfeiture proceedings directed against contraband or forfeitable property."171 The rationale for this proposition, if taken as true, is a peculiar result of parallel apphication doctrine. Since a criminal defendant who is herself the "fruit" of an unlawful seizure is not "suppressed"-set free, in other words-parallel application of the rule to forfeiture cases deinands that the defendant in forfeitures, the "guilty" res, reinain similarly unsuppressed. The logical result would be that the illegally seized res is admissible at all stages of the forfeiture proceeding. Such an exception would entirely swallow the rule. It would be particularly threatening where the forfeitable res is hard currency, since some courts have found the mere presence of large

170. 468 U.S. 1032 (1984).

171. Id. at 1039-40. 
amounts of cash sufficient for probable cause. ${ }^{172}$

The Court's dicta on forfeiture rules is not currently accepted law in the lower courts and, as one commentator has pointed out, none of the cases the Court cites as authority in Lopez-Mendoza actually stand for the Court's proposition. ${ }^{173}$ The lower court cases stand instead for the idea that illegal seizure does not bar the eventual forfeiture of the res through the use of untainted evidence, discussed above in Section III.B.2. The Court apparently misunderstood these cases or decided to spell out the full imphications of parallel doctrine. Whatever its intentions, the Court has opened the door for lower courts to routinely admit illegally seized property as evidence in civil forfeiture proceedings.

The ultimate disposition of Victorino Hernandez' \$38,000 demonstrates the consequences of the formalistic parallel application of the exclusionary rule to forfeiture cases. The district court granted Hernandez' motion for summary judgment because the court was troubled by "the government's 'cavalier disregard for the Fourth Amendment." 174 The district court recognized that the "mere exclusion of unconstitutionally seized property. . . is of no practical effect" in forfeiture proceedings, and sought a "sharper deterrent."175

Reasserting the parallel application doctrine, the court of appeals reversed the judgment while admitting that "the agents seized the $\$ 37,780$ on the strength of its existence and little else." 176 Without addressing the deterrence rationale underlying the exclusionary rule, the appellate court restated the principle that illegal seizure does not bar the eventual forfeiture of the res through proof by untainted evidence. ${ }^{177}$ The court then turned to what it termed the Supreme Court's "suggestion" in INS v. Lopez-Mendoza "that in a civil forfeiture proceeding the exclusionary rule does not apply to the forfeitable property itself." 178 Following that suggestion, the court held the cash admissible, and found the government to have probable cause based on the illegally seized cash itself, and the evidence obtained subsequent to the seizure of the cash-both of which were admissible only as a result of the parallel application doctrine. ${ }^{179}$ The court ultimately remanded the case to give Hernandez an opportunity to meet his burden of proof to regain the money. ${ }^{180}$

172. See, e.g., United States v. $\$ 55,518.05$ in U.S. Currency, 728 F.2d 192, 196 (3d Cir. 1984) (suggesting that "[f]or most Americans, $\$ 55,518$ is not casual pocket change which one leaves on the bureau overnight").

173. See SMITH, supra note 31, at I 10.05[9].

174. United States v. $\$ 37,780$, 920 F.2d 159, 163 (2d Cir. 1990).

175. Id. at 161 .

176. Id. at 162 .

177. Id. at 163 .

178. Id.

179. Id.

180. Id. at 164. There are also other possible dysfunctional implieations of parallel application. 


\section{The Need for Specific Disincentives}

The parallel application of the exclusionary rule to forfeiture cases almost entirely undermines the rule's deterrent goals. Because the rule poses few threats in the forfeiture context, it has little impact on law enforcement agents' decisions about whether to comply with Fourth Amendment standards. Whether the constable blunders, blusters, or obeys, the ranch does not go free. Some seizures will breach Fourth Amendment standards; others will not. Since neither situation generally presents a bar to forfeiture, both situations must be equal in the eyes of law enforcement; the outcome is positive in both. The danger is that this may provoke an attitude of mdifference to the commands of the Fourth Amendment, an attitude of carelessness-or worse.

From an instrumental perspective, it may make sense for law

For example, in United States v. Janis, 428 U.S. 433 (1976), the Suprenie Court permitted the use of tainted evidence in federal civil tax proceedings when the illegal search and seizure was conducted by state police officers. The court relied on the nitersovereign relationship and differing objectives of the state and federal agencies in concluding that no deterrent purpose would be served by the application of the exclusionary rule.

In evaluating the need for a deterrent sanction, one nust first identify those who are to be deterred. In this case it is the state officer who is the priniary object of the sanction. It is his conduct that is to be controlled. Two factors suggest that a sanction in addition to those that presently exist is unnecessary. First, the local law enforcement official is already "punished" by the exclusion of evidence in the state criminal trial. That, necessarily, is a substantial concern to him. Second, the evidence is also excludable in the federal criminal trial, so that the entire criminal enforcement process, which is the concern and duty of those officers, is frustrated.

Id. at 448 (footnote omitted).

In adoptive forfeiture cases where state or local law enforcement officers have illegally procured evidence, the government could analogize to the civil and intersovereign nature of the Janis case in an attempt to justify the admission of the evidence. This is despite some dicta in Janis distinguishing forfeitures as "quasi-criminal" proceedings. Id. at 447 n.17. Further, Janis should be inapplicable since the intersovereigu nature of federal forfeitures of state or local law enforcement seizures is considerably blurred by the equitable sharing program. State and local law enforcenient quite obviously benefit from the federal proceeding. This tactic apparently has been attempted in only two forfeiture cases under 21 U.S.C. $\$ 881$. In one iustance, it was successful. See United States v. $\$ 280,505,655$ F. Supp. 1487, 1498 (S.D. Fla. 1986) ("The Motion to Suppress is denied because evidence seized by state criminal law enforcement officers im good faith, but nonetheless illegally, is adniissible in civil actions brought by or against the United States." (citing Janis, 428 U.S. at 45960)). Perhaps unsure of its ruling, the court held in the alternative that the search in question was in fact lawful. Id. at 1498. The other court to consider the issue found the opposite. See United States v. One Ford $198 X$ Mustang, 749 F. Supp. 324, 327-29 (D. Mass. 1990). The court was apparently persuaded by the fact that the forfeiture suit was based entirely on the tainted evidence. Id. at 328 .

A final application of parallel application doctrine allows one to read the Suprene Court's opinion in United States $v$. Calandra as rendering the exclusionary rule wholly inapplicable at the probable cause stage of civil forfeiture cases. In Calandra, the Supreme Court held that the exclusionary rule was inapplicable to grand jury hearings. 414 U.S. 338, 351-52 (1974). An analogy exists between grand jury hearings and the probable cause stage of a forfeiture case, which supports the use of hearsay evidence to establish probable cause. See supra text accompanying note 53. Relying on this analogy, a court might use parallel application doctrine to apply Calandra to a forfeiture case and hold that the exclusionary rule is entirely irrelevant to the showing of probable cause. While no court has yet characterized the issue in this nanner, such an approach would eliminate the relevance of the exclusionary rule in the great majority of federal civil forfeiture actions. 
enforcement im pursuit of forfeiture to embark on a pattern of recklessness im search and seizure, or even a considered policy of Fourth Amendment violations. This is particularly true $\mathrm{m}$ situations where the value of the assets forfeited is likely to be large. Taking the time to procure a search warrant or meet the other demands of the Fourth Amendment might result in the loss of desirable assets. There is little reason to be cautious as a formality, and every reason to aggressively pursue the asset.

The lack of any real deterrent threat attached to Fourth Amendment violations in forfeiture cases may even generate further instances of the undesirable conduct. Professor Andenaes refers to this effect as the infectiousness of the "bad example."181 He describes it this way:

The more violations, the fewer qualms the individual feels .... The unthinkable becomes thinkable when comrades are doing it. Why should one be honest when others are not? The risk seems less real; moral inhibitions are broken down. This danger is probably greatest when an individual learns about offenses committed by others who are in similar situations. ${ }^{182}$

So when Fourth Amendinent violations produce only a positive result for the violators-law enforcement agents-these "bad examples" provide little reason for agents to alter their behavior, and every reason to engage further in such violations, particularly since it is so inuch easier than compliance with nebulous standards of reasonable suspicion and probable cause.

One could argue to the contrary that the traditional application of the exclusionary rule to criminal proceedings sufficiently deters law enforcement imisconduct in all activities, including the pursuit of forfeiture. The fallacy of this arguinent is its assumption that law enforcement views criminal charges and forfeitures as indissolubly linked. The Supreme Court has noted the ineffectiveness of the exclusionary rule in situations that differ from the norm of the criminal trial:

Regardless of how effective the rule may be where obtaiming convictions is an important objective of the police, it is powerless to deter invasions of constitutionally guaranteed rights where the police either have no interest im prosecuting or are wilhing to forgo successful prosecution in the interest of serving some other goal. ${ }^{183}$

As discussed above in Section III.B.1, forfeiture presents just such a case. There is a need, then, for a mechamism desigued to gain law enforcement compliance with Fourth Amendment standards that is tailored to forfeiture. The ultimate goal is to propose a rule that transcends the criticisms levelled at the exclusionary rule-that it is ineffective in ensuring compli-

181. Andenaes, supra note 128 , at $55-56$.

182. Id. at 56 .

183. Terry v. Ohio, 392 U.S. 1, 14 (1968) (footnote omitted). 
ance with the Fourth Amendment and is too costly to society. In the wake of the changes that forfeiture has brought, such a rule may be possible.

\section{IV \\ Proposal for Reform: A Designed Disincentive}

This Comment argues that the surest way to gain law enforcement compliance with Fourth Amendment standards in the forfeiture context is to threaten law enforcement with loss of the assets if it does not adhere to constitutional requirements. The rule would be configured in a simple and in many ways familiar fashion:

Upon appropriate motion by the claimant in a forfeiture proceeding, otherwise forfeitable assets obtained in violation of the claimant's constitutional right to be free from unreasonable searches and seizures will be summarily returned to the claimant and not subject to forfeiture. ${ }^{184}$

The threat is familiar because it resembles the exclusionary rule im criminal proceedings; it is designed to achieve the same effect as that rule. Like the exclusionary rule, the proposed rule places at risk the primary objective of a certain law enforcement action, thus introducmg a meaningful disincentive for law enforcment misconduct. The threat is also simple because of its familiarity to all the parties involved-the court, the governinent, the counsel for the claimant, and most importantly, the law enforceinent officers.

Despite its facial similarity, and the similarity of its intent to that of the exclusionary rule, the proposed rule's operation is structurally different. The exclusionary rule focuses on the admissibihty of evidence, while the proposed rule has a more basic demand-it demands that law enforceinent agents adhere to Fourth Amendment standards when they pursue forfeitable assets. If law enforceinent agents breach those standards, then the asset may not be forfeited, regardless of evidentiary questions. As a result, there is good reason to believe that the proposed rule would generate substantial compliance with Fourth Amendinent standards when agents engage in instrumental pursuit of forfeitable assets.

\section{A. Effectiveness of the Proposed Rule}

The powerful incentives that drive law enforceinent agents and agencies to pursue forfeitable assets simultaneously create conditions within those agencies that make them amenable to an external sanction such as the one proposed here. If forfeited assets are important to law enforcement agencies, then denymg agencies that goal when they violate

184. Compare this with the summary of the exclusionary rule in Francis A. Allen, The Exclusionary Rule in the American Law of Search and Seizure, in Police PowER AND INDIVIDUAL FrEedom 77 (Claude R. Sowle ed., 1962). 
the Fourth Amendment will reduce the instances of violation. The intuitive truth of this formula is powerful.

An examination of what underlies that intuition reveals the strengths of the proposed rule. It seems to envision a law enforcement agency as a unitary whole, an organism with some central locus of decisionmaking, much like the "dispassionate customer peering at a price list in search of barganis, perfectly informed and perfectly rational,"185 which informs the simplest model of deterrence. Yet this image contrasts starkly with the image of the pohice suggested by criticisms levied at the exclusionary rule, the proposed rule's doctrimal parent. Critics of the exclusionary rule envision a police force as a collection of individual agents with broad discretionary powers, to whom the outconne of a criminal trial is unimportant and only dimly communicated in any event, and to whom external sanctions are mediated by powerful police norms that have a blunting effect on external legal threats.

These two contrasting visions of the threatened audience-law enforcement agencies-would seem to be mutually exclusive. A comparison of the functional contexts of the exclusionary rule and the proposed rule, however, demonstrates that the incentives to pursue forfeiture may generate conditions within law enforcement agencies which justify imposing an external sanction based on a vision of the agency as a unitary rational actor.

Although it would be impossible to identify and categorize all of the factors which influence the deterrent outcome of a given legal threat, it is helpful for the present task to outline the broad categories of the most influential ones. Professors Zimring and Hawkins have identified a number of these determinant factors, four of which seem critical when the behavior to be deterred is illegal search and seizure by law enforceinent agents. These four are the influence of group pressure, ${ }^{186}$ the applicability and credibility of the threat, ${ }^{187}$ the communication of the threat, ${ }^{188}$ and the type of threatened behavior. ${ }^{189}$

\section{Group Pressures}

There are at least two situations where group pressures affect the efficacy of the deterrent threat:

1. Often a person will be forced to make a decision about his response to a threat that might become visible to other members of his group, in which case strong pressures to conform to group expectations will be generated by the prospect that his decision will become known.

185. ZimRING, supra note 124 , at 3.

186. Id. at 96-97; ZIMRING \& HAWKINS, supra note 124, at 209-24.

187. ZIMRING, supra note 124, at 65-73; ZIMRING \& HAWKINS, supra note 124, at 158-72.

188. ZIMRING, supra note 124, at 56-65; ZIMRING \& HAwKINS, supra note 124, at 141-57.

189. ZIMRING, supra note 124, at 49-55; ZIMRING \& HAWKINS, supra note 124, at 128-41. 
2. In a smaller number of cases, groups rather than individuals are the relevant unit of criminal participation; in such cases, the reaction to legal threats will be collective rather than individual. ${ }^{190}$

If there is strong group pressure to heed the legal threat, the deterrent effect of the threat will be increased, and individual meinbers of the threatened group will be less likely to engage in the threatened activity. If, on the other hand, there are strong group pressures to ignore the threat, then the deterrent effect of the threat will be reduced, and the result will be the opposite.

Critics of the exclusionary rule have often focused on the role police culture plays in inediating the effectiveness of externally imposed rules. ${ }^{191}$ They argue that there is a powerful set of group norms in law enforcement agencies that "are more powerful than court decisions in shaping police behavior, and that actually the process of interaction between the two accounts ultimately for how police behave."192 These critics argue that pohice group norms eliminate inuch or all of the deterrent effect of the exclusionary rule, since they neutralize the sting of the exclusionary threat.

[T] he worst that can happen to the individual policeman for an illegal searcl is loss of a conviction as a result of the exclusionary rule. Superiors within the police organization will, however, be in sympatly witl an officer, provided the search was administratively reasonable, even if the officer did not have legal "reasonable" cause to make an arrest. ${ }^{193}$

Police superiors and admimstrators typically are former beat cops who share a common world view with their subordinates, a world view which often competes with the perspectives of outsiders seeking to control law enforcement conduct. Such outsiders "articulate a moral order-a systein of values and norms," while "the police are organized to articulate a behavior system-to maintain law and order . . . ."194 Thus, the meaning of "reasonable" search and seizure as constructed by a judge (it is within the bounds of the Fourth Amendment) is different froin its meaning as constructed by a law enforcement agent (it achieves soine perceived pohice function). ${ }^{195}$

190. ZIMRING, supra note 124 , at 96 .

191. See SxolNiCX, supra note 143 , at 219-29.

192. Id. at 219.

193. Id. at 223.

194. Oaks, supra note 140, at 728 (quoting Albert J. Reiss \& Donald J. Blanck, Interrogation and the Criminal Process, 374 AnNals 47, 48-49 (1967)).

195. It is part of the policeman's job to locate and confiscate illegal substances. Thus, even if a search revealing possession of an unlawful weapon or an unlawful narcotic was conducted [unlawfully], the policeman would have done part of his job simply through the act of retrieval. By failing to make the putatively "reasonable" search, the policeman would not only have failed to gain a conviction, but would also have missed collecting objects or substances regarded as dangerous. In the policeman's view, only good can come out of a search legally defined as "unreasonable," provided the search jibes with the normative assumptions of the police organization about reasonableness. 
Professor Skolnick has pointed out that since police agents possess this distinct world view and value system, they "fail[ ] to respond to judicial interpretations of legality. Instead, [their] allegiance is to police organization and its evaluative standards." 196 As long as officers act within the scope of police standards, no internal sanction will accompany the external sanction. Rather than discipline from superiors and disapproval from other law enforceinent agents, the "offending" officer will receive sympathy, understanding, and shared frustration with the "unreasonable" demands of judges. 197

Witliout an accompanymg internal sanction, the external sanction (exclusion of illegally obtained evidence at trial) is a threat without teeth. The law enforcement agent defines her worth according to the assessment of other agents and of the law enforcement institution, rather than the assessment of an outsider like a judge. ${ }^{198}$ Thus, "there are no strongly compelling reasons for the policeman to do well in ways that do not count in terms of . . . occupational criteria of value."199 If these occupational criteria do not reflect the values underlying the exclusionary rule, then the rule's deterrent effect will be limited.

Commentators have long poimted out that an internal disciplinary sanction is essential to control police conduct.

[P]rimary dependence for the control of police conduct must, under any conditions, contimue to be placed upon existing systems of internal discipline. An agency functioning outside a police department simply does not liave the capacity to substitute for the numerous eclielons of supervisory officers that are required around the clock, twenty-four liours a day, to provide the kind of on-tlie-spot direction and control that is necessary to assure conforimity by liundreds and sometimes thousands of police officers to establislied standards of conduct. ${ }^{200}$

This poimt has been made most forcefully by supporters of a police rulemaking model, under which law enforcement agencies themselves would use a unodified form of admimistrative rulemaking to create internal standardized procedures and guidelmes for behavior. ${ }^{201}$ Supporters

\footnotetext{
SKOLNICK, supra note 143 , at 220.

196. Id. at 227.

197. Id. at 225-27.

198. See id. at 227.

199. EgON BITtNer, The Functions of THE POLICE IN MOdern Society 55 (National Inst. of Mental Health, Public Health Service Pub. No. 2059, 1970).

200. Herman Goldstein, Administrative Problems in Controllling the Exercise of Police Authority, 58 J. Crim. L. Criminology \& Police SCI. 160, 161-62 (1967).

201. See, eg., KeNnETh C. DAvis, DisCretionary JustiCe 52-161 (1969) (discussing ways for administrative bodies to create internal controls on discretionary justice); Anthony $G$. Amsterdam, Perspectives on the Fourth Amendment, 58 MiNN. L. REv. 349, $415-39$ (1974) (advocating police rulemaking to govern search and seizure procedures); Goldstein, supra note 200, at 171-72 (arguing that police controls must be internalized to be effective); Wayne R. LaFave, Controlling Discretion by Administrative Regulations: The Use, Misuse, and Nonuse of Police Rules and Policies in Fourth Amendment Adjudication, 89 MicH. L. REV. 442, 447-51 (1990) (discussing
} 
argue that due to the mediating effect of police norms, law enforcement agents are more likely to obey internally created rules than externally imposed ones, and when rules are disobeyed, police department discipline systems are likely to be better enforcers of the rule.

According to the rulemaking view, then, the task of externally imposed sanctions is not to structure a national or statewide standard of police practice, or to punish individual officers. Rather, the purpose of external sanctions is to stimulate police agencies to consciously structure policies that comply with the Fourth Amendment and "induce a desire and willingness on the part of pohice administrators and their supervisors to elicit conformity from their subordinates."202

In light of the influence of group norms on individual behavior, any analysis of the possible deterrent effect of a rule such as the one proposed in this Comment must start with the basic assumption that police norms will powerfully mediate the effect of any threat on imdividual agents. This mediation of the external threat is not inevitably inimical to deterrence, however. This seems true only because it is so often true, as in the case of the exclusionary rule.

Forfeiture has already changed law enforcement norms in a singularly significant way. Whereas the nltimate disposition of a criminal suspect at trial may affect law enforcement institutional interests only mildly if at all, ${ }^{203}$ the ultimate disposition of forfeitable assets directly affects institutional interests. First, the monies derived from forfeiture aid the agency officially, providing a deep funding reservoir that is beyond direct political control. Equally important are the spoils of forfeiture-extra manpower and equipinent. The prospect of new guns, surveillance equipinent, vehicles, and other matériel makes forfeiture an attractive proposition to a police force which normally perceives the benefits of what it does only dimly and indirectly.

If individual law enforcement agent action results im the loss of forfeitable assets, that agent's action would be counter to the powerful group norms for successful confiscation. If breaching Fourth Amendment standards ineans forfeiture is denied, the breach would then be contrary to police group norms defining action that is "reasonable," and therefore subject to group lostility. Unlike the exclusionary rule context, then, in forfeiture there is the possibility of aligning external, "outsider" norms, and internal police norms.

arguments for and benefits of internal rulemaking regarding the Fourth Amendment). The rulemaking movement seems aimed more at what Amsterdam calls arbitrary searches and seizuresFourth Amendment activities that do not reach the courts and subsequently are not subject to review. Amsterdam, supra, at 411; see also LaFave, supra, at 448-49. Although the concern in the forfeitures context is not with arbitrary searches-far from arbitrary, they are instrumental-but with unjustified searches, the insights of rulemaking about internal structures retain their validity.

202. Goldstein, supra note 200, at 161-62.

203. See supra Section III.B. 
The result of this alignment would be external and internal sanctions for Fourth Amendment breaclies, because the loss of forfeitures affects law enforcement in a way that the loss of convictions does not. Offending law enforcement agents would be subject to both unofficial group disapproval and official disciplinary action, particularly when the lost property is of considerable value or violation of the group norm is more than occasional.

Because forfeiture is linked to group imterests, the proposed rule works in a way that the exclusionary rnle cannot; it forces police agencies to become involved in the activities of individual agents to ensure their compliance with Fourth Amendment standards. The beneficial consequences of internal pressure are many:

"[I]n this manner the process contains a number of the elements so seriously lacking in some of the most commonly proposed systems for controlling police conduct. It operates on the top police administrator, thereby applying pressure to the entire agency rather than to imdividual police officers. It focuses upon administratively tolerated and continuing patterns of police violations, rather than isolated incidents of wrongdomg. It is more concerned with preventing such violations in the future than in providing redress for the past. And it has the potential for contributing, in a very significant way, to stimulating police agencies to better control their personnel ....,"204

The proposed rule would effectively liarness the mediating effect of police norms and values, and channel them into a powerful force for securing compliance with Fourth Amendment standards.

\section{Applicability, Credibility, and Communication of the Threat}

A threatened audience must know it is threatened for there to be any deterrent effect. However, communication is more than just delivering the message:

[E]ffective communication will require delivering the message to a threatened audience, presenting the message in ways that will make members of the threatened audience pay attention and remember the information being conveyed, and, if possible, associating the information contained in the threat with the threatened behavior in the minds of audience members so that their recollection of the terms of the threat will be greatest when it is most needed. ${ }^{205}$

If the message is not delivered persuasively, if it is vague or unclear about

204. LaFave, supra note 201, at 499 (quoting HeRMan Goldstein, Policing a FreE SOCIETY 179 (1977)). LaFave here is discussing a process by which a court would order a police agency to articulate and submit for review a set of policies for various types of police activities. Given the powerful institutional pressures driving law enforcement pursuit of forfeiture, there is no need for such an explicit command; the rule barring forfeiture should generate this type of rulemaking on its own.

205. ZIMRING, supra note 124, at 59; see also ZIMRING \& HAwkINS, supra note 124, at 141-58. 
how it applies to the threatened behavior, then its deterrent potential will be diminished.

The related criteria of apphicability and credibility further vary the effectiveness of the legal threat. For a legal threat to be effective, the inembers of the threatened audience must be convinced of two things. First, they must believe that the threat is applicable to them. An audience that believes a legal threat is aimed at a different audience is less likely to fear the imposition of consequences and to adjust its behavior accordingly. ${ }^{206}$

Second, the threatened audience must be convinced that the threatening agency is willing and able to detect and punish instances of the threatened behavior; the threat must be credible. ${ }^{207}$ Audience perceptions of the probability of punishment affect the deterrent result of the threat: if the penalty for parking in a red zone is death, but there are no meter maids, then the threat will not be credible and the deterrent outcoine will be minimal.

Critics of the exclusionary rule liave commented that the threat of evidence suppression falls primarily on the prosecutor, not the police, ${ }^{208}$ because it impedes the prosecutor's ability to convict suspects but not the police officer's ability to get them to the courthouse. This criticism raises issues of applicability, credibility, and communication of the threat as einbodied in both the exclusionary rule and the proposed rule.

First, the exclusionary threat seems unlikely to convince law enforcenient agents thiat it is apphicable to them rather than the prosecutor. The notion that suppression of evidence at trial will deter law enforcenient misconduct presupposes that law enforcenient agents are primarily prosecution-oriented. However, this assuniption is not supported by evidence. As discussed above in Section IV.A.1, law enforcement group norms value a wide variety of police behaviors, nıany of which are not oriented towards prosecution of offenders. One of the central insights derived fron the "discovery" of police discretion in the 1960 s was that law enforcement agents engage in a range of activities inılicating the Fourtl Amendnient which are never subject to review since they are not carried out with a court date in mind. ${ }^{209}$ The direction of the legal threat toward the courtroon, a relatively unimportant aspect of law enforcenient practice, cannot lope to convince law enforcenient agents that the threat is meant to apply to thein. As a result, "the exclu-

206. ZIMRING, supra note 124, at 66; ZIMRING \& HAWKINs, supra note 124, at 158-60.

207. ZIMRING, supra note 124, at 67; ZIMRING \& HAWkINS, supra note 124, at 160-63.

208. See, e.g., Oaks, supra note 140 , at 726-27.

209. See generally SkOLNICK, supra note 191, at 71-90 (examining police discretion in issuing and processing traffic citations); Josepl 1 Goldstein, Police Discretion Not to Invoke the Criminal Process: Low-Visibility Decisions in the Administration of Justice, 69 YALE L.J. 543 (1960) (discussing police decisions not to invoke the criminal process, and suggesting ways to increase the visibility and review of suclı decisions). 
sionary rule is well tailored to deter the prosecutor from illegal conduct," 210 but not the law enforcement agent.

Second, the fact that much Fourth Amendment pohice activity is not oriented towards prosecution also limits the credibility of the exclusionary rule threat. A large chunk of law enforcement activity never reaches the courtroom, and thus is not even threatened by the rule. The threatenimg agency's ability to detect and punish violations is questionable if the threat only addresses a small portion of the violative activity.

Third, since the exclusionary rule's sanction falls primarily on the prosecutor, the effectiveness of the threat's cominunication to its ultimate target-the offending law enforcenient agent and agency-is also questionable. Under the exclusionary paradigm, commission of the threatened behavior (by police) is followed by the threatened consequences (which fall on the prosecutor), and this information somehow niakes its way back to the pohice. However, the channels of communication between police and prosecutor have come under fire as being severely flawed:

"Nor are police well informed about the trial judge's decision or its legal basis. The trial judge seldom explains his decision in a way likely to be understood by the police officer, and the prosecutor assigned to the case rarely assumes it to be his duty to inform the police department of the meaning of the decision or its intended impact upon current police practice. The individual officer whose case has been lost is not expected to report the reason for the decision to his superiors. . . Obviously, police cannot be affirmatively influenced to change their methods of law enforcement by the exclusion of evidence when there is no communication to them of why the decision was inade."211

Although commentators on the exclusionary rule have recently noted improvement $\mathrm{m}$ the chamels of cominunication between prosecutors and police, ${ }^{212}$ this aspect of the exclusionary rule remains a linuiting factor on its deterrent effect.

In the context of asset forfeiture, the applicability, credibility, and commumication of the exclusionary threat to law enforcement agents are not so limited. Forfeiture directly affects law enforcenient. Althouglı law enforcement values and norms may not be prosecution-oriented, there can be hittle doubt that they are forfeiture-oriented for agencies in pursuit of forfeitable assets. The proposed rule poses a real threat to law

210. Oaks, supra note 140 , at 726.

211. Id. at 730 (quoting Wayne R. LaFave \& Frank J. Remington, Controlling the Police: The Judge's Role in Making and Reviewing Law Enforcement Decisions, 63 MICH. L. REV. 987, 1005 (1965)).

212. Jonathan Simon \& Jerome H. Skolnick, Federalism, the Exclusionary Rule, and the Police, in Power Divided: Essays on THE Theory and Practice of Federalism 79-84 (Harry N. Scheiber \& Malcolm M. Feeley eds., 1989). 
enforcement imterests by barring forfeiture when Fourth Amendment standards are breached.

The proposed rule does suffer from the same type of credibility problems as the exclusionary rule in that it only addresses instances of Fourth Amendment violation where forfeiture is the goal, leaving a wide variety of Fourth Amendment activity untouched. However, the powerful lure of forfeitures and the frequency and vigor with which they are pursued should amehorate this effect. Drug offenses-the source of forfeitable assets-have long been among the most persistent and serious source of Fourth Amendment misconduct by law enforcement. ${ }^{213}$ Since law enforceinent agents presumably have hittle ability to predict in which suspected drug offense situations there will be valuable forfeitable assets, the credibility of the threat would seem to apply across a broad range of worrisome police activity. In every situation in which forfeitable assets may be present, there wonld be a strong incentive to adhere to Fourth Amendment standards. ${ }^{214}$ Second, there can be no question of the threat's credibility when there is an asset produced for forfeiture. The threatening agency, the court, is capable of detecting and willing to punish each and every incidence of poice lawlessness that comes before it.

The threat embodied in the proposed rule wonld also be commumcated much more directly and coinpellingly, than the exclusionary threat. The exclusionary rule affects the outcome of the criminal trial, a late stage in the law enforceinent process which typically is of only indirect and reactive interest to police agencies. In contrast, law enforceinent agencies are likely to take an active interest in forfeiture proceedings, because of the potential institutional benefits. If forfeiture is barred under the proposed rule, law enforcement agents and their superiors are going to actively seek an explanation, and they are going to figure out how to avoid similar results in the future.

\section{Type of Threatened Behavior}

Cominon sense dictates that the effectiveness of a deterrent sanction varies with the type of threatened behavior; certain types of activity are more deterrable than others. For instance, many people would conclude intuitively that bank robberies are more deterrable than drug use. This intuition can be analyzed by examiming four axes. First, different types

213. See Oaks, supra note 140 , at $681 \mathrm{n} .69,682$.

214. This would seem to be a broader effect than the exclusionary rule has on all potential drug offense situations. Consider Skolnick's description of the exclnsionary rule, supra note 195, in this context. A good example would be United States v. \$280,505, 655 F. Supp. 1487, 1491 (S.D. Fla. 1986). In that case, police officers pulled over a car for reckless driving and flecing a police officer, searched the car's interior for weapons, and found a snitcase contaiming $\$ 265,000$, as well as $\$ 15,085$ in the glove compartment and door pouch. It is the fear of losing this type of serendipitons find which would generate Fourth Amendment compliance by law enforcement agents. 
of people are likely to engage in different types of activity; ${ }^{215}$ these differences vary the effectiveness of a given deterrent sanction, since different types of people react to an external threat in different ways. Second, a threatened audience may have stronger or weaker internal barriers to the coinmission of one activity as opposed to another, regardless of the external threat. ${ }^{216}$

Third, different types of threatened behavior may be inore or less strongly inotivated. ${ }^{217}$ The stronger the motivations for a particular behavior, the less effective the legal threat will be in deterring that behavior. Finally, apart froin the relative strengths of motivations to act, there are different emotional contexts to those motivations. ${ }^{218}$ Some threatened activities are instrumental; typically committed for economic gain, they serve as a means to soine clear goal. Bank robbery and einbezzleinent are examples. Other activities are expressive; actors engage in thein not to attain some end, but simply because the act is valuable to the actor in and of itself. Vandalisin is a good example. Along these hines, instrumental activities would seem more deterrable than expressive activities. $^{219}$

In the context of typical law enforcenent activity, it is questionable whether the motives to breach Fourth Amendment standards are of a strength and type susceptible to an externally imposed deterrent threat. Critics of the exclusionary rule have pointed out that the rationale behind the rule presupposes "police have a God-given inclination to commit unconstitutional searches and seizures unless they are 'deterred' from that behavior,"220 whereas the real motivation seems far more coinplex: the features and deinands of the police occupational environment interact with and shape pohice group norms and values, making obedience to external legal coinmands less important than obedience to perceived internal expectations. Given this complexity of motivation, gaining law enforcement comphance with the Fourth Amendinent is a difficult task for any external sanction.

The motivation for law enforcement to pursue forfeiture, however, and to violate the Fourth Amendment in the process, is far simpler. Instead of enforcing soine internally mediated version of the penal law against wrongdoers, law enforcement agencies in pursuit of forfeiture are doing something more akin to making use of an enabling statute for fundraising purposes. The inotive in many ways boils down to a fainiliar

215. ZIMRING, supra note 124, at 50; ZIMRING \& HAWKINS, supra note 124, at 131-32.

216. ZIMRING, supra note 124, at 50-51; ZIMRING \& HAWKINS, supra note 124, at 132-34. Put simply, there are plenty of good reasons apart from the threat of punishment not to commit murder, but there are fewer good reasons not to make a left turn across a double yellow line.

217. ZiMRING, supra note 124, at 51-53; ZIMRING \& HAWKINS, supra note 124, at 134-36.

218. ZIMRING, supra note 124, at 53; ZIMRING \& HAWKINS, supra note 124, at 136-38.

219. ZimRing \& HaWkiNs, supra note 124 , at 138-39.

220. Amsterdam, supra note 201 , at 431 . 
one-profit. We understand this type of motive; classical models of economic rationality are built upon it. Concepts of deterrence and disincentive make sense within this framework. Institutions and actors become more like the rational calculators of cost and benefit which the simiplest model of deterrence envisions.

Under this straightforward cost-benefit model, it makes sense to impleinent a rule, like the one proposed in this Comment, that weighs heavily on the "cost" side of the equation im order to diminish law enforcement breaches of Fourth Amendment standards. The more valuable the potentially forfeitable asset, the greater the "cost" when law enforcement agents commit unconstitutional searches. Rational actors weighing their alternatives can come to only one course of action, which is to diminish the instances of the threatened behavior.

\section{B. Implementation}

There are real-world pohicy questions to ask when implementing such a broad rule: what agency has the authority and resources to implement such a rule and what will the implementation costs be? For the proposed rule, the difficulty of implementation is not minimizmg costs, but finding a body that is willing to implement the rule at all.

The judiciary seems to be the most suitable institution to implement the proposed rule, for reasons of both tradition and logic. For the courts, the fashioning and managenent of such a rule is by no means an unfamiliar project. The Supreme Court is the parent of the structurally similar exclusionary rule and has developed a whole body of law concerning how, when, and where it shonld be apphed. ${ }^{221}$ It is only natural to look to the Court to implement the proposed rule, given its past leadership in trying to curb law enforcement violations of the Fourth Amendment.

Because of its functional similarity to the exclusionary rule, the proposed rule would pose only minimal impleinentation costs for all parties involved. For judges, prosecutors, and defense attorneys, there is a preexisting mechanism for hearing suppression claims that could easily accomodate forfeiture suppression claims. There is also a pre-existing body of Fourth Amendment doctrine to guide magistrates in evaluatimg suppression claims. Nor is the proposed rule unfamiliar to pohice. It allows no claim that it imposes yet another layer of legal restrictions upon law enforcement's ability to do its job. There is no extra doctrine to learn, no special set of rules to obey outside of the rules police are already required to obey by virtue of the Fourth Amendment.

Not only are the costs of implementing the proposed rule negligible, but the Court's own logic supports adoption of the rule. The Court has

221. For a description of the development of the exclusionary rule, see Oaks, supra note 140, at 667-72. 
continually relied on the rationale of deterrence to narrow the scope of the exclusionary rule; in a given situation, if the Court does not perceive that rule to achieve an appreciable deterrent effect when weighed against the perceived social costs of the rule, the Court refuses to apply it. It is time to call the Court's bluff on its deterrence logic. If the Court is serious about the central importance of deterrence, it should recognize that the exclusionary rule's parallel application to forfeiture proceedings works little or no deterrent effect at all. To be consistent, then, the Court inust either refuse to apply the exclusionary rule to forfeitures at all, since the deterrent effect is marginal, or it must alter the rule along the lines proposed in this Comment to achieve tlie deterrent effect originally intended. 222

The exclusionary threat is widely regarded to liave been a failure for familiar reasons: it doesn't deter, and even if it does, it exacts social costs that are simply too high. Lower courts' atteinpts to fashion a functionally equivalent rule for forfeiture are likely to be rejected, as was the district court's attempt in United States $v$. $\$ 37,780^{223}$ to look beyond the superficial application of the exclusionary rule to tlie rule's avowed purpose. This is unfortunate, since the rule proposed here offers a greater lope for deterrence than its predecessor at a decidedly lower social cost. $^{224}$

\section{Social Costs}

"[T]he criminal is to go free because the constable has blundered."225 This early criticism of the exclusionary rule by Justice Cardozo points to two negative collateral effects of the suppression sanction. First, since exclusion typically means that the prosecution will not be able to prove its case, a guilty individual will go unpunislied for lis deeds. Second, society as a whole suffers, since the criminal reniains at large. This result exacts social costs by failing to reduce public fear of crime, and by lowering public confidence in tle criminal justice systen.

222. However, the rule proposed in this Comment is unlikely to be greeted with much enthusiasm by the current Court regardless of how compelling the Court's own logic is for the rule's implementation. The rule's similarity to the politically disfavored exclusionary rule makes it a poor candidate. There is good reason to believe that a inajority of the current Supreme Court members dislike the exclusionary rule, would not have supported it had they been on the Court for Mapp v. Ohio, 367 U.S. 643 (1961), and would uphold a legislative alternative to the rule if Congress proposed one.

223. 920 F.2d 159, 163 (2d Cir. 1990); see supra text accompanying notes 174-79.

224. The rule could also easily be implemented by the federal legislature. Congress wrote 21 U.S.C. $\S 881$, the federal forfeiture statute; it could just as easily amend it to include the proposed rule. However, the exclusionary rule suffers from the same image problem in Congress as it does in the Court, so this route of implementation is unlikely as well. See H.R. 4079, 101st Cong., $2 \mathrm{~d}$ Sess. (1990). This bill would lave eliminated use of the exclusionary rule im drug eases. Sponsored by Rep. Newt Gingrich, the bill had 58 cosponsors.

225. People v. Defore, 150 N.E. 585, 587 (N.Y.), cert. denied, 270 U.S. 657 (1926). 
The operation of the Suppression Doctrine unhappily brings to the public gaze a spectacle repugnant to all decent people-the frustration of justice. . . . If [people] coine to believe that law enforceinent is being frustrated by what laymen call 'technicalities,' there develops a sour and bitter feeling that is psychologically and sociologically unhealthy.... [A] vast nuinber of people are losing respect for law and the administration of justice because they think the Suppression Doctrine is defeating justice. $^{226}$

These "objectionable collateral consequence[s]"227 seem to have driven recent Supreine Court decisions limiting or narrowing the application of the exclusionary rule; the Court has simply found the social costs to outweigh the deterrent effect of the rule. ${ }^{228}$ Any proposal for a new rule of suppression must be prepared to answer these criticisins.

Consider the forfeiture-era counterpart to Justice Cardozo's statement embodied by the proposed rule- "The ranch is to go free because the constable has blundered." It seeins silly to suggest that this is objectionable in the same sense as the original. In forfeitures, the freedom of the real target of the proceeding - the drug offender-is never at issue. The question is whether the government may deprive the supposed violator of her tainted property. Regardless of the outcome of the forfeiture proceeding, the property owner remains free unless criminal charges are filed. And it is, after all, the property owner, not the property, who has committed any underlying crimes.

This is not to say that forfeiture does not pumish property owners; it does. One could argue that there is a social cost in allowing drug offenders to enjoy the material benefits of their trade. The notion that drug crime pays, and pays well, resounds im our society. A rule such as the one proposed here might hinder law enforcement efforts to stop such drug crime.

The reality is, however, that most people whose assets are forfeited are not criminals. Eighty percent of forfeiture claimants were not or could not be charged with any crime. ${ }^{229}$ Moreover, studies of forfeiture mdicate that the vast inajority of forfeiture suits are not against the "luxurious playthings of drug barons, but modest homes and simple cars."230 What law enforcement officials depict as "poetic justice" is not quite so uphifting im practice.

226. Warren E. Burger, Who Will Watch the Watchmen?, 14 AM. U. L. REv. 1, 12, 22 (1964).

227. United States v. Leon, 468 U.S. 897, 907 (1983).

228. See, e.g., INS v. Lopez-Mendoza, 468 U.S. 1032, 1040-50 (1984) (rule not applicable in civil deportation proceedings); Leon, 468 U.S. at 922 (rule not applicable to violations of Fourth Ainendment where officer acted in "good faith" belief in validity of search warrant); United States v. Jacobsen, 466 U.S. 109, 113-22 (1984) (rule not applicable to private-party searches subsequently reported to law enforcement agents); Rakas v. Illinois, 439 U.S. 128, 133-34 (1978) (limiting standing to invoke protection of the rule).

229. Schneider \& Flaherty, supra note 52, at A1.

230. Id. 
Most crucially, the proposed rule does not affect the traditional inethod for punishing criminals, which is arresting thein and proving their guilt beyond a reasonable doubt. Nor does the proposed rule have an appreciable effect on public fear of crime or confidence in the criminal justice system. It is easier to imagine an indignant citizen railing against the criminal justice system, outraged that a "technicality" ruined the government's criminal case against an alleged drug dealer, than it is to imagine the same citizen, outraged that a "technicality" foiled the forfeiture of the suspect's house.

The collateral social costs of the proposed rule are thus limited, and far less than the perceived social costs of the rule's stepsister, the exclusionary rule. In conjunction with the probable efficacy of the proposed rule in diminishing instances of law enforcement misconduct, the rule's ininimal social costs strongly support its adoption.

\section{CONCLUSION}

The need for a new rule on asset forfeiture must be understood in context. The great inajority of forfeiture proceedings do not involve unlawful searches and seizures. Nor would the proposed rule put an end to law enforceinent breaches of Fourth Amendment standards, either in the context of forfeiture or external to it. But the danger of the current situation is real. At present there is no significant disincentive for law enforcement agents faced with the opportunity to violate the Fourth Amendment when forfeiture is the goal. Combined with the powerful incentives driving the pursuit of forfeiture, this creates a dynamic where constitutional constraints on search and seizure are likely to be disregarded.

Any proposal to create a deterrent threat through an external sanction will likely meet hittle enthusiasm in the federal legislature and courts of the 1990s. The branches of government seem far more inclined to limit such rules than expand them. This is an unfortunate result. The rule proposed here, which would bar forfeiture when the res is the fruit of an unconstitutional search and seizure, would have a powerful deterrent effect on law enforcement violations of the Fourth Amendinent.

Constitutional boundaries on police procedure urgently need to begin to catch up with the forfeiture laws, which expanded in the 1980s, propelled by a national fever to fight drugs and by law enforcement's fever to forfeit assets. Asset forfeitures should not be excepted from constitutional requirements simply because their objects-drug criminals and their property-are also objects of national scorn. As one judge has put it:

Our society is today engaged in a vital struggle against crime, generally, and the illegal distribution and use of drugs, specifically. This is a struggle which I, like any other responsible citizen, fully support. But judicial 
obligations, as I understand them, go beyond the popular disposition of cases. I believe it is my duty to object when the government abridges the constitutional rights of a citizen, notwithstanding the purity of its motives or its justification when viewed in the hight of the final outcome.

....

... Were we to [refrain from objection], it would in my view amount to holding that because appellant is an alleged drug dealer, he is entitled to less process under the Constitution than is due other citizens. If history has taught us anything it is that such short cuts, although popular at their inception, are in the long run harmful to our democratic form of government. 231

This Comment suggests the need for a rule which would ensure that no such short cuts are taken in the unseemly race to the res. ${ }^{232}$

231. In re Kingsley, 802 F.2d 571, 580, 583 (1st Cir. 1986) (Torruella, J., dissenting). The judge objected to the pre-indictment seizure of the claimant's home, with the concomitant eviction of the claimant, based upon mere probable cause.

232. The phrase is from United States v. Alston, 717 F. Supp. 378, 380 (M.D.N.C. 1989) (referring to a dispute between the federal government, a local police department, and a local school board as to the federal adoption of a local asset seizure which otherwise would have been forfeited under the state forfeiture statute, with the proceeds going to state schools), aff'd sub nom. United States v. Winston-Salem/Forsyth County Bd. of Educ., 902 F.2d 267 (4th Cir. 1990). 
